\title{
Etiudy Romana Polańskiego
}

Images

vol. IX/no. 17-18

Poznań 2011

ISSN 1731-450X
Kiedy w 1954 roku, po zdaniu egzaminu, 21-letni Roman (Romuald) Polański pojawił się w łódzkiej Szkole Filmowej jako student I roku reżyserii, nie był postacią nikomu nieznaną. W hierarchii panującej wówczas na uczelni i wśród studentów, na samym początku musiał co prawda dobijać się o uznanie wśród starszych roczników, ale po pewnym czasie jego pozycja w środowisku stała się czymś oczywistym i niekwestionowanym, zarówno pod względem towarzyskim, jak i artystycznym. Romek od początku był kimś.

Uważano go wtedy bez porównania bardziej za aktora niż reżysera. Nic dziwnego, bowiem nie było wśród studentów PWSF nikogo, kto legitymowałby się tyloma rolami i epizodami zagranymi początkowo w teatrze, potem w filmie. Jako ktoś wielce uzdolniony i obiecujący, został zaprotegowany przez wykładowcę Szkoły Antoniego Bohdziewicza, który zobaczył go po raz pierwszy na scenie w tytułowej roli w socrealistycznym przedstawieniu Syn pułku w Teatrze Młodego Widza (1953). Polański - jeszcze nie będąc studentem Szkoły Filmowej pojechał na plan filmowy do Bielska-Białej i zagrał u Konrada Nałęckiego w drugiej noweli Trzech opowieści (1953). Tam właśnie poznał znakomitego operatora Jerzego Lipmana. To on otworzył Polańskiemu oczy na kino i sztukę filmową, pierwszy wprowadził go w jej arkana, a także sprawił, że rok później Andrzej Wajda powierzył mu rolę Mundka w swoim debiucie Pokolenie (1954).

Gdy tylko znalazł się w Łodzi na Targowej, jego talenty aktorskie zostały natychmiast zagospodarowane zarówno w profesjonalnej kinematografii, jak i na potrzeby etiud studenckich. Na pierwszym roku studiów zagrał więc nie tylko kolarza Adasia w Zaczarowanym rowerze Silika Sternfelda (1955), lecz również wystąpił w dwu etiudach studenckich: najpierw (o czym dawno zapomniano) udzielając swego głosu narratorowi zza kadru w ekranizacji fragmentu Antka Bolesława Prusa, którą reżyserowała Leokadia Migielska (1955), a następnie - już z osobistym udziałem aktorskim na ekranie - $\mathrm{w}$ roli Chłopca w etiudzie fabularnej Pawła Komorowskiego Godzina bez słońca (1955).

Nakręcona latem 1954 roku w Krakowie szkolna etiuda fabularna w reżyserii Pawła Komorowskiego warta jest po latach przypomnienia. Wprawdzie Roman Polański nie reżyserował tego filmu, jednak jego przemożna w nim rola i osobisty wpływ, jaki przez swoją obecność na ekranie w roli głównej wywarł ostatecznie na charakter całości, należą bez wątpienia do zasadniczych. Co tu dużo mówić: bez
Godzina bez stońca 
udziału Polańskiego ta podszyta duchem Poematu pedagogicznego, sławnego traktatu Antona Siemionowicza Makarenki moralistyczna opowiastka o wyrządzonym złu (sztubacka kradzież zabytkowego świątka ze zbiorów wawelskich) i jego finałowej naprawie (podrzucenie skradzionego przedmiotu przez nawróconego na właściwą drogę

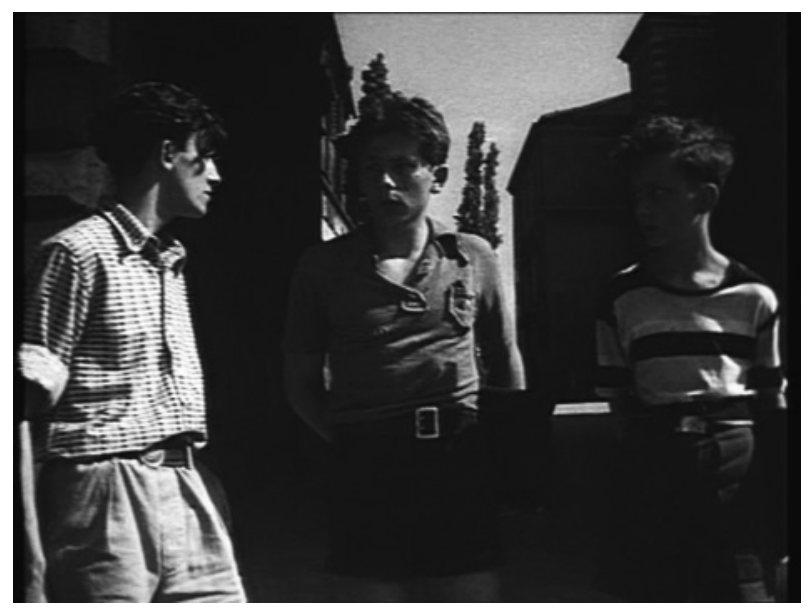

sprawcę w pobliże miejsca przestępstwa) byłaby trudna do strawienia ze względu na swój natrętnie podany widzowi na tacy morał.

$\mathrm{Z}$ biegiem lat etiuda fabularna Pawła Komorowskiego zagubiła swój moralistyczny wydźwięk, odsłaniając w jego miejsce swoje całkiem inne walory, w tym zwłaszcza niewątpliwe zalety realizacji. Należą do nich: sprawność filmowego opowiadania, kapitalnie sfotografowany przez studenta IV roku Wydziału Operatorskiego Jerzego Wójcika Kraków z połowy lat pięćdziesiątych (piękne panoramy miasta, ulica Kanonicza, Podwale, Wawel i Dziedziniec Wawelski, skrzyżowanie Grodzkiej i Dominikańskiej) oraz, last but not least, aktorstwo Romana Polańskiego.

Zdumiewa znakomita sprawność aktorska młodego filmowca zaprezentowana w tym filmie. Nic dziwnego, w końcu aktorem postanowił zostać $\mathrm{w}$ wieku lat trzynastu, a na planie filmowym pojawił się po raz pierwszy na długo przed studiami w Łodzi i to od razu - jako profesjonalista całą gębą - w mówionej drugoplanowej roli Małego w nowelowym filmie Trzy opowieści (1953). Wiadomo było, że ma już w tamtym momencie całkiem spory dorobek jako aktor filmowy, włącznie z - okrojoną, niestety, w montażu z przyczyn cenzuralnych rolą drugoplanową, którą zagrał w Pokoleniu (1954).

Ciekawy jest wątek kolarski jego biografii zarówno własnej, jak i aktorskiej. Wkrótce po ukończeniu Godziny bez słońca Polański wystąpił w roli Adasia w pełnometrażowym filmie sportowym pt. Zaczarowany rower w reżyserii Silika Sternfelda (1955). Do ról kolarzy był zresztą predestynowany jak mało kto. W Godzinie bez słońca młody Romek występuje przez cały czas w krótkich spodniach, w odróżnieniu od swoich partnerów demonstrując wyjątkowo mocne i umięśnione nogi sportowca uprawiającego w tamtym czasie amatorsko kolarstwo. Ścigał się na zarówno torze kolarskim, jak i w wyścigach ulicznych i szosowych. Jego osobistym marzeniem stało się posiadanie roweru wyścigowego. Kolarstwo było bez wątpienia sportem numer $1 \mathrm{w}$ Polsce lat pięćdziesiątych, dzięki popularności Wyścigu Pokoju Warszawa-Berlin-Praga bardziej niż piłka nożna czy boks kształtując wtedy masową wyobraźnię milionów Polaków. 
Otrzaskanie i umiejętności aktorskie, jakie zyskał Polański dzięki udziałowi w paru filmach, były w tamtym czasie jego wielkim atutem. Przed kamerą czuje się jak ryba w wodzie. Nie chodzi przy tym tylko o samą naturalność jego zachowań, lecz o coś więcej, mianowicie o świadomość sceny, sytuacji filmowej, w której uczestniczy, i umiejętność zbudowania przyciągającej uwagę widza postaci bohatera. Widać, że procentuje tutaj profesjonalne doświadczenie aktora zdobyte przez niego wcześniej na planie zdjęciowym wspomnianych uprzednio filmów fabularnych: Trzy opowieści (nowela II Jacek - w roli Małego, reż. Konrad Nałęcki, 1953) i wspomniane już Pokolenie Andrzeja Wajdy (bardzo trudna jako zadanie aktorskie drugoplanowa rola Mundka, w znacznej mierze wycięta w wersji ekranowej, 1954).

W trakcie kilkunastominutowej opowieści, jaką zawiera Godzina bez słońca, obserwujemy wagary trójki bohaterów - chłopaków w wieku licealnym w krótkich spodniach ze szkolnymi teczkami pod pachą. Naprawdę jednak, bohater jest tylko jeden. W ciągu kilku pierwszych scen filmu dokonuje się na naszych oczach to, co wielokrotnie opisywali później przyjaciele i koledzy Polańskiego ze studiów. Roman błyskawicznie przejmuje przywództwo i inicjatywę w tym tercecie i nie oddaje jej już do końca. „Irytował mnie ten jego ciągły popis. Mówił głośno, zakrzykiwał mnie, nie dał dojść do słowa. Zabierał mi pole!" - wspominał po latach Henryk Kluba. A Janusz Majewski nie bez podziwu dodawał: „Był gotów udowodnić pilotowi odrzutowca, że lepiej od niego zna się na pilotażu. Miał nieustanną potrzebę dokumentowania, że jest kimś. Zawsze chciał wszystkich zdominować." Są też inne wspomnienia dotyczące młodego Polańskiego z okresu jego studiów w Łodzi. „Romek zawsze wygrywał tym, że młodo wyglądał. Wtedy, mając po dwudziestce, wyglądał jak nastolatek” - tak właśnie zapisał się w pamięci Witolda Leszczyńskiego. „Pokolenie Polańskiego, Kostenki, Kondratiuka - dodawał z uznaniem Andrzej Wajda - stało się w Szkole początkiem czegoś zupełnie nowego i niewyobrażalnego. Myśmy naśladowali naszych ojców, wszystko było w nas przedwojenne, łącznie z dobrym wychowaniem. Natomiast Polański jawił się jako potwór. Że kogoś takiego przyjęli do Szkoły? Koniec świata! Do czego to wszystko zmierza?! A zmierzało do październikowych wydarzeń."[1]

Szersze spojrzenie na etiudę „Godzina bez słońca” każe po latach docenić przede wszystkim jej warsztat i zespołową robotę: od scenariusza aż do montaż. Trzeba też podkreślić imponujący wręcz wysiłek produkcyjny Uczelni. Rok akademicki 1954/1955 przyniósł w łódzkiej Szkole Filmowej rekordową w porównaniu z poprzednimi laty liczbę filmów nakręconych przez studentów Wydziału Reżyserii i Wydziału Operatorskiego. Powstało ich wówczas ogółem aż 65! 
Działo się to w okresie ekranowej posuchy, w czasie, kiedy w Polsce realizowano coraz mniej filmów fabularnych przeznaczonych do wyświetlania w kinach.

$\mathrm{Na}$ tle pozostałych etiud Godzina bez słońca korzystnie się wyróżnia, scena po scenie odsłaniając współczesnemu widzowi rozmaite swe walory.

Dla historyka Krakowa nieocenioną wartość mają niezwykłej urody zdjęcia filmowe, będące dziełem Jerzego Wójcika i jego zdolnego asystenta Witolda Sobocińskiego. Od pierwszej do ostatniej sceny miasto żyje na ekranie, a doskonała fotografia wydobywa i podkreśla uroki jego niepowtarzalnej aury. „Godzina bez słońca” Pawła Komorowskiego jest filmem zasługującym też na większą niż dotąd uwagę biografów Romana Polańskiego. Wprowadza bowiem doskonale w temat początków jego kariery aktorskiej, pokazując na czym polegał fenomen jego niezwykłej osobowości.

Rower

Nie wiadomo, czy kiedykolwiek zobaczymy Rower, pierwszą etiudę studencką Romana Polańskiego, nakręconą przez niego w roku 1955. Prawdę mówiąc, wydaje się to mało prawdopodobne. Zapewne nie obejrzymy jej już nigdy, skoro w rezultacie niesłychanego bałaganu, jaki z powodu natłoku zleceń (w związku z V Światowym Festiwalem Młodzieży i Studentów w Warszawie) zapanował wtedy w warszawskim Laboratorium Filmu Polskiego, negatyw gdzieś zaginął. Podczas wywoływania kolorowego materiału zdjęciowego nakręconego przez łódzkich studentów ocalała tylko pierwsza partia negatywu. Wielka szkoda. Gdyby nie sam reżyser i jego własna pamięć, wiedzielibyśmy o tym filmie jeszcze mniej.

Po pierwsze, rzutki i przedsiębiorczy student pierwszego roku wszedł w posiadanie czegoś na owe czasy bezcennego, a mianowicie: kilkuset metrów kolorowej taśmy. Po drugie, jak zawsze miał nosa, zaprzyjaźniając się ze swoim starszym kolegą, studentem czwartego roku Wydziału Operatorskiego, Nikołą (Kolą) Todorowem. To właśnie Todorow został operatorem debiutanckiej etiudy Polańskiego. Po trzecie, nikomu nieznany debiutant zamierzał opowiedzieć historię z własnego życia i ów autobiograficzny aspekt stale obecny w jego filmowej twórczości - jak nieraz bywało później - już wtedy dał o sobie znać.

Historię nakręcenia Roweru opisał dość szczegółowo Polański w tomie swoich wspomnień zatytułowanym Roman[2]. Wynika z niej jasno, że tematem filmu stał się dramatyczny epizod zaczerpnięty z własnego życiowego doświadczenia. Chodziło o zdarzenie, w którym omal nie zginął z ręki parokrotnego mordercy, niejakiego Janusza Dziuby, który pod pretekstem zakupu sportowego roweru zwabił go do bunkra w centrum Krakowa i tam podstępnie zaatakował, parokrotnie uderzając swą ofiarę w głowę kamieniem.

[2] Zob. R. Polański, Roman, przeł. K. i P. Szymanow-

skich, Warszawa 1989, ss. 98-99. 
Ogłuszony kilkoma uderzeniami, niedoszły kolarz z twardą czaszką cudem uszedł z życiem. Kto inny na jego miejscu po odratowaniu i wyjściu ze szpitala próbowałby pewnie o wszystkim jak najszybciej zapomnieć. Tymczasem Polański zafundował sobie na kanwie tamtego zdarzenia osobliwą autoterapię, jadąc ze swoją ekipą do Krakowa, aby tę historię na miejscu sfilmować $\mathrm{z}$ sobą $\mathrm{w}$ roli napadniętego i z Adamem Fiutem (rodowitym krakowianinem z Grzegórzek, studentem II roku Wydziału Aktorskiego) w roli wspomnianego rzezimieszka Dziuby.

Całość opowiadanej historii, rzucona na tło życia codziennego w dużym mieście po wojnie, została przypuszczalnie sfilmowana w konwencji zbliżonej do dreszczowca ( $\mathrm{z}$ akcentem na krew lejącą się $\mathrm{z}$ rany napadniętego i potężnie ugodzonego nieszczęśnika), przy jednoczesnym udziale chwytanych na gorąco scenek rodzajowych. Polański zaplanował zdjęcia w taki sposób, aby pokazać poszczególne epizody autentycznych sceneriach (krakowski bazar) i na ulicach, na których toczy się normalne codzienne życie.

Wypada raz jeszcze wyrazić żal z powodu utraty tego filmu pierwszej studenckiej etiudy nakręconej przez przyszłego mistrza kina u progu jego reżyserskiej kariery. Gdyby owa debiutancka etiuda szczęśliwie się zachowała - byłby to dzisiaj niewątpliwy rarytas, godny nie tylko obejrzenia, ale i uważnego przestudiowania.

Ten króciutki filmik nie jeden raz służył w przeszłości jako egzemplifikacja vouyeurystycznego motywu obecnego „od zawsze” w twórczości Polańskiego. Nie sądzę, aby trzeba było motyw vouyeuryzmu podnosić do rangi klucza interpretacyjnego tak prostej opowiastki, jak ta, którą opowiada w swoim filmie młody autor. Chodziło raczej o żart z dowcipną zaskakującą pointą, który zmieści w ramach niewielkiej studenckiej etiudy. Ale nawet tutaj widać, jak utalentowany student, realizując ćwiczenie warsztatowe, próbuje zaprezentować coś więcej niż poprawny warsztat.

Mamy więc doskonale zaaranżowaną filmowo scenerię, na którą składa się klatka schodowa w kamienicy oraz wnętrze łazienki. Układ architektoniczny decydujący o relacji pomiędzy jednym a drugim sprawia, że przestrzeń wspólna (schody) i przestrzeń z założenia osobna i intymna (łazienka na półpiętrze) nie są od siebie całkowicie oddzielone. Nie są - ze względu na istnienie okna, które umożliwia podglądanie ze schodów osoby znajdującej się w łazience. W roli podglądacza wystąpił Kola Todorow. Intruz, mężczyzna w płaszczu i szaliku zagląda do środka przez okratowane (co dodatkowo wzmaga efekt zakazanego owocu) okienko. Ów brak stuprocentowej intymności, którą z łatwością ktoś drugi może naruszyć, nie jest czymś wymyślonym. Był on codziennym doświadczeniem milionów ludzi żyjących w bylejakich warunkach, w powojennej ciasnocie i prowizorce.

Uśmiech zębiczny nie miał jednak na celu dokumentowania czegokolwiek. W grę nie wchodziła etiuda nie dokumentalna, lecz 
fabularna. Chodziło w tym ćwiczeniu o skonstruowanie prościutkiej jednowątkowej mikroopowieści fabularnej z zaskakującym suspensem na końcu. Od strony produkcyjnej, jej akcja miała się rozgrywać w jednym miejscu i w jednej lokacji zdjęciowej. Trzeba przyznać, że Polańskiemu i jego starszemu o dwa lata koledze, operatorowi Henrykowi Kucharskiemu owo ćwiczenie reżysersko-operatorskie nieźle się w sumie udało. Sytuacja ekranowa i punkt widzenia kamery zostały z sobą precyzyjnie sprzężone i umiejętnie skorelowane pod względem dramaturgicznym.

Tytuł filmu sugeruje jednoznacznie, iż w centrum zainteresowania autora znajduje się właśnie ów obleśny uśmieszek podglądacza, który śledzi poranną toaletę stojącej przed lustrem młodej urodziwej kobiety. Jej uroda, powab i naturalny spokój towarzyszący wykonywaniu porannego rytuału zostały brutalnie skonfrontowane z brzydotą lubieżnej czynności znajdującego się po naszej stronie voyeura. Montażowa antyteza nie tylko kładzie kres samemu podglądaniu, ale i sprowadza na widza symboliczną karę. Neologizm „zębiczny” w połączeniu $\mathrm{z}$ fatalnym stanem uzębienia aktora - niesie z sobą ostry i przykry efekt turpistyczny, o co autorowi tego żartu niewątpliwie chodziło.

Kulisy realizacji Uśmiechu zębicznego okazują się bardzo proste. Roman Polański, podobnie jak kilku jego kolegów, między innymi: Jan Rutkiewicz, Jerzy Orawiec, Henryk Kluba i Janusz Majewski, został w 1957 roku studentem Andrzeja Munka, który wkrótce po nakręceniu Człowieka na torze rozpoczął zajęcia na Wydziale Reżyserii PWSF w Łodzi. Tamtego roku podopieczni Munka studiujący reżyserię otrzymali do zrobienia jednakowe zadanie na ten sam temat. Tematem reżyserskiego ćwiczenia $\mathrm{z}$ wyobraźni, z którym mieli się zmierzyć młodzi filmowcy, był uśmiech. Wyraz 'uśmiech' miał również figurować w tytule filmu. Wszystkie etiudy powinny być optymalnie zwięzłe i krótkie, zawierając tylko jeden epizod. Trzeba przyznać, że Polański poradził sobie $\mathrm{z}$ tym niełatwym zadaniem w sposób wyjątkowo pomysłowy i zręczny, tworząc tyleż atrakcyjną, co dowcipną opowiastkę, zawierającą w sobie reprezentatywną próbkę cech stylistycznych, jakie znamy z jego późniejszych filmów.

Uśmiech zębiczny wydaje się utworem kłopotliwym do objaśnienia dla kogoś, kto - jak gros interpretatorów twórczości Polańskiego - z upodobaniem stosuje do analizy klucz czy też raczej wytrych autobiograficzny. Nie ma tutaj żadnych przesłanek ani przekonujących podstaw do tego, by w taki właśnie sposób objaśniać nieskomplikowaną króciutką historyjkę, jaka została w nim opowiedziana. Kontekst ów wydaje się tyleż atrakcyjny, co zwodniczy i generalnie zbędny. Zarówno Uśmiech zębiczny, jak i inne etiudy Polańskiego nie zawierają, moim zdaniem, jakiejś szczególnej dozy pierwiastka autobiografizmu, która wyróżniałaby je na tle innych etiud studenckich kręconych wówczas w Łodzi. W każdym razie nie trzeba wcale znać biografii ich twórcy, aby zrozumieć i ocenić jakąkolwiek z nich. 
Powie ktoś, a wizja świata? Otóż to! Problem w tym, że w bardzo wielu znanych mi pracach o Polańskim i jego filmach przewija się - pochopnie i na wyrost przyjęte przez badaczy - założenie, iż nie sposób przeniknąć i pojąć tej twórczości bez uprzedniego uwzględnienia jej aspektu autobiograficznego. Życie autora miałoby tutaj explicite objaśniać i pomagać zrozumieć filmy, jakie nakręcił. Jedno wynika jakoby bezpośrednio z drugiego. Ma o tym rzekomo świadczyć zawarta $\mathrm{w}$ nich mroczna wizja świata, wielorako korespondująca $\mathrm{z}$ dramatycznym życiowym doświadczeniem autora.

Rozróżnijmy w tym miejscu wyraźnie dwie różne kwestie. Czym innym jest coś, co prywatny człowiek nazwiskiem Roman Polański sądzi osobiście o świecie. A czym innym - oryginalna wizja świata wykreowana w jego filmach. Oba te fenomeny bynajmniej nie są z sobą tożsame, ani też nie nakładają się jeden na drugi. W procesie interpretacji danego filmu mogą one co najwyżej współistnieć, egzystując komplementarnie względem siebie. Hipoteza autobiograficzna nie jest jednak absolutnie konieczna ani też niezbędna, by móc trafnie odczytywać, rozumieć i interpretować którykolwiek z jego filmów. Nie jest ona też w ogóle potrzebna widzowi, podkreślmy, nawet wtedy, gdy sam twórca expressis verbis naprowadza nas na taki właśnie biograficzny trop.

Niezmiernie trudno odtworzyć nam dzisiaj dydaktyczny zamysł, sens i klucz do zadania, jakie dziesiątki lat temu otrzymał młody student reżyserii, przystępując w roku 1957 do nakręcenia króciutkiej etiudy fabularnej zatytułowanej Morderstwo. Nie wiemy nawet, czy była to etiuda reżyserska czy operatorska studiującego wówczas w Łodzi Nikoły Todorowa? A może ich obu jednocześnie? Obecnie nie ma to już większego znaczenia.

Na ekranie wszystko trwa bardzo krótko, zaledwie niecałe osiemdziesiąt sekund. Całe zdarzenie rozgrywa się w zupełnej ciszy i milczeniu (ćwiczenie nie miało mieć dźwięku). Wraz z niemą kamerą, jako widzowie, stajemy się - zaskoczonymi i oniemiałymi z wrażenia - świadkami popełnianej na naszych oczach zbrodni. Reżyser postanowił zawrzeć tę makabryczną historię w formie najbardziej lapidarnej z możliwych: w zaledwie czterech ujęciach.

Dwa z tych ujęć - pierwsze i ostatnie - pełnią funkcję ramy kompozycyjnej, zawierając w sobie obraz białych drzwi pokojowych wraz $\mathrm{z}$ nieruchomą klamką. W ujęciu pierwszym klamka z wolna uchyla się, drzwi otwierają się. W ujęciu ostatnim oglądamy scenę, w której starszy człowiek wychodzi z pokoju, zamykając za sobą drzwi - te same, którymi przed momentem wszedł. Ich statyczny widok z klamką w centrum kadru kończy cały film. Wewnątrz tej ramy reżyser umieścił dwa inne, znacznie dłuższe ujęcia, w których rozgrywa się dramatyczne wydarzenie. Podobnie jak narrator, przebywamy w obcym nieznanym miejscu, jesteśmy w naszej pozycji widza usytuowani przez cały czas wewnątrz jakiegoś pokoju w roli biernego obserwato- 
ra. Popełnione w naszej obecności z zimną krwią - nieporadnie, choć w końcu najzupełniej skutecznie - zabójstwo szokuje nas i jednocześnie wciąga na prawach hipnotycznego przeżycia naszą percepcję, zamieniając się w makabryczny ekranowy spektakl.

Nieznane miejsce, nieznajomy przybysz, nieznajomy lokator tego pokoju leżący w łóżku i pogrążony we śnie - jak się okazuje - na moment przed własną śmiercią. Szczególnie zaskakuje nas jako widzów porażająca chwila, w której niewprawny napastnik stara się wbić nóż dokładnie w serce półnagiej ofiary, a młody mężczyzna daremnie usiłuje wyrwać mu się i uratować życie. Ugodzony prosto w serce, zastyga z dłonią tuż nad podłogą i ręką zwieszoną z łóżka, po której spływa krew. Podczas gdy my mamy teraz okazję przyjrzeć się lepiej mordercy. Ku naszemu zdziwieniu, sprawcą zbrodni okazuje się całkiem zwyczajnie wyglądający starszy mężczyzna w okularach, czarnym płaszczu, kapeluszu i z laską w dłoni. Co więcej i co dziwi szczególnie: okrutny oprawca, jakiego oglądaliśmy przed chwilą w akcji, okazuje się całkiem zwyczajnym człowiekiem o niegroźnym, nieco gapowatym wyrazie twarzy, na której dostrzegamy uśmiech zakłopotania, a nie groźny grymas zbira. „Fabuła filmu - pisała Grażyna Stachówna - została przedstawiona zupełnie serio. Można ją odbierać jako rekonstrukcję autentycznego zdarzenia, ale także jako upostaciowanie koszmaru, dręczącego kogoś po nocach, albo jako projekcję czyjejś sadystycznej wyobraźni. Z ekranu emanuje strach i okrucieństwo - śpiący, bezbronny człowiek, tajemniczy morderca, nóż, drgające ciało, krew." [3]

W dalszym ciągu swych rozważań cytowana autorka wyprowadza na podstawie Morderstwa i Dwóch ludzi z szafa szersze wnioski dotyczące filmowego voyeuryzmu jako powtarzalnego i na swój sposób charakterystycznego motywu, który przenika całą późniejszą twórczość Romana Polańskiego. Motyw ten organizuje nie tylko rodzaj więzi pomiędzy autorem a wirtualnym adresatem filmu, lecz także typowe dla Polańskiego sposoby konstruowania narracji filmowej w ich relacji ze światem przedstawionym. Dotyczy to zwłaszcza dwóch najważniejszych wyznaczników narracji filmowej, a mianowicie: sytuacji ekranowej i punktu widzenia.

„Voyeuryzm” jako koncepcja psychoanalityczna zrobił w latach osiemdziesiątych sporo karierę w akademickiej refleksji filmoznawczej, najpierw we Francji, potem w krajach anglosaskich. Nie należę do zwolenników voyeurystycznego konceptu w badaniach narratologicznych nad filmem. Wydaje mi się on mało efektywny, za to efektowny, by nie powiedzieć efekciarski z przypisanym do niego założeniem uniwersalności zastosowania, które zdaje się wszechobjaśniać każdy, nawet najbardziej złożony charakter narracji prowadzonej za pośrednictwem ruchomych obrazów. 
Rezerwa, jaką zachowuję wobec tego rodzaju procederów analityczno-interpretacyjnych, wynika z krytycznej obserwacji praktyki badawczej. Nie chodzi tutaj o modę, jaka panowała przez pewien czas wokół tej koncepcji, lecz o mizerne poznawcze rezultaty, jakie przynosiła. Wielokrotnie stykałem się $\mathrm{z}$ pracami, w których nadużywane w swym znaczeniu pojęcie „Voyeuryzmu” (cokolwiek miałoby ono znaczyć) stanowiło nie tyle słowo-klucz, co wytrych, stając się narzędziem forsownych nadinterpretacji i rozmaitych intelektualnych nadużyć. Ich ofiarą niejeden raz padał także sam Polański.

Jeśli odrzucić wielokrotnie później stosowany przez badaczy tej twórczości wytrych naiwnego biografizmu i całkiem nieuprawnionego psychologizmu, który na pozór zdaje się wiele tłumaczyć i wyjaśniać, a w końcu prowadzi interpretatora w ślepy zaułek ignotum per ignotum - sam motyw obojętnego przypatrywania się rzeczywistości przez zdystansowanego narratora wart jest jednak uwagi badacza tych filmów. Wytwarza on bowiem typowy dla sposobu opowiadania przez reżysera efekt obcości, wynikający z umiejętnie podtrzymywanego stałego napięcia między tym, co niesie z sobą filmowany spektakl życia, a zdystansowanym obojętnym spojrzeniem kamery i narratora-widza jako (przygodnych, przypadkowych lub nieprzypadkowych, kwestia do dyskusji) świadków rozgrywających się zdarzeń. Motyw ten należy niewątpliwie do struktury głębokiej przekazu, organizując - na różnych piętrach konstrukcji - jego poetykę.

Ma rację Grażyna Stachówna, upatrując właśnie w nakręconej w 1957 roku, a więc bardzo wczesnej, etiudzie Morderstwo laboratoryjny przykład poetyki Polańskiego. Trzeba jednak najpierw odpowiedzieć sobie na podstawowe pytanie: czy sfilmowane przez niego zdarzenie bliższe jest pojęciu akcji, czy też fabuły? Rzecz w tym, że autor filmu zrobił wszystko, by oczyścić popełniane na naszych oczach morderstwo z jego jakichkolwiek fabularnych uzasadnień. Akcja zdecydowanie góruje tu nad fabułą. Uwolniona od fabularnego schematu i wyzwolona od jego presji, podąża we własną stronę, odkrywając przed nami swój całkowity bezsens i absurdalny wymiar.

Ekranowym światem i zdarzeniem, do którego w nim doszło, rządzi bowiem absurd. Świat, jaki Polański ukazuje w swoich filmach, pełen jest zła, przemocy i okrucieństwa. Oglądamy coś, czego nie potrafimy w żaden sposób zrozumieć ani wyjaśnić. Nie znajdujemy wytłumaczenia. Nie umiemy ująć tej zbrodni, której przypadkowymi świadkami jesteśmy, w logiczny ciąg zdarzeń, w łańcuch powiązanych z sobą przyczyn i skutków. Nie jest to imitacja popełnionego niegdyś 
zabójstwa, lecz ono samo ukazane in statu nascendi, tu i teraz - jako fakt tyleż naoczny, co absurdalny.

Punkt wyjścia tej dokumentalnej etiudy zawierał w sobie następującą kwestię: co stanie się, gdy banda chuliganów gapiących się po drugiej stronie wysokiego metalowego parkanu nagle sforsuje pałacowe ogrodzenie, wedrze się nocą na strzeżony teren, na którym odbywa się szkolna potańcówka, i z całą brutalnością zaatakuje jej uczestników, tłukąc pochłonięte zabawą bezbronne towarzystwo bez opamiętania. Wiadomo mniej więcej, co może się wówczas stać. Rzecz w tym, że ktoś zaplanował cały incydent i zamierza go przy pomocy paru kamer zamienić w filmowy dokument.

Przystępując do realizacji Rozbijemy zabawę (1957), Polański postąpił wbrew wszelkim regułom i elementarnym kanonom realizacji obowiązującym film dokumentalny jako rodzaj filmowy. Zaplanował całe zdarzenie, wybrał miejsce (ogrodzony wysokim parkanem teren nieopodal pałacyku Szkoły Filmowej) zaangażował biorących w nim udział uczestników, rozdał im zadania i podzielił na dwie antagonistyczne grupy. $\mathrm{Z}$ całą starannością wyreżyserował też wyjściową sytuację, która miała doprowadzić do konfliktu przed kamerą, z góry przewidując jej rozwój. W gruncie rzeczy, chodziło o zdokumentowanie na taśmie filmowej przebiegu eksperymentu psychospołecznego, a jego organizator i zimny rejestrator $\mathrm{w}$ jednej osobie postąił jak wytrawny badacz psycholog w rodzaju Philipa Zimbardo. Tyle że „efekt lucyfera” wywołał środkami filmowymi i osiągnął na planie zdjęciowym kilkadziesiąt lat wcześniej niż jego sławny amerykański następca.

Rozbijemy zabawe jest filmem jak na owe czasy wysoce nowatorskim i poniekąd przełomowym w rozwoju artystycznym młodego adepta sztuki filmowej, studenta III roku reżyserii PWSF, Romana Polańskiego. Jest również etiudą krótkometrażową, która przeszła do legendy i przez wiele następnych roczników inspirowała jego następców i naśladowców, by wspomnieć tylko młodszy o kilkanaście lat wyczyn reżyserski Feriduna Erola i Marka Piwowskiego. W nakręconej przez nich dziesięciominutowej dokumentalnej (sic!) etiudzie studenckiej pod tytułem Kirk Douglas (1967) zastosowano tę samą co w Rozbijemy zabawę metodę preinscenizacji. Polegała ona na wywoływaniu dla potrzeb filmowego spektaklu zbiorowego happeningu poprzez umiejętne aranżowanie sytuacji, podział ról i prowokowanie serii zdarzeń rozgrywających się przed kamerą.

Ciekawe, że o genezie i kulisach realizacji swego filmu Polański opowiada po latach (na kartach wspomnieniowej książki „Filmówka”) „poprzez Munka”. Jak wynika z relacji reżysera, to właśnie Andrzej Munk, ówczesny mistrz i mentor młodego adepta reżyserii zgodził się na realizację tej dokumentalnej etiudy, akceptując jednak tylko wyjściowy zamysł sfilmowania szkolnej zabawy - dodajmy, bez specjalnego entuzjazmu dla oryginalności przedstawionego projektu. Autor fil- 
mu Rozbijemy zabawę powołuje się po latach na inspirację ideą cinéma vérité. Brzmi to szlachetnie, ale niekoniecznie prawdziwie - jeśli spojrzeć na rzecz z historycznofilmowego punktu widzenia. Niekoniecznie prawdziwie, bowiem w 1957 roku idea ta, która niebawem miała zrobić oszałamiającą zaiste karierę nie tylko na gruncie kinematografii francuskiej, ale generalnie w kinie światowym, dopiero torowała sobie drogę do świadomości, ergo trudno się nią było inspirować.

Film wywołał w Szkole skandal. Wydawało się, że jego autora spotkają przykre konsekwencje. „Wściekli byli na mnie głównie studenci, a nie wykładowcy" - wspominał po latach Polański. Ostatecznie skończyło się na ostrzeżeniu komisji dyscy-

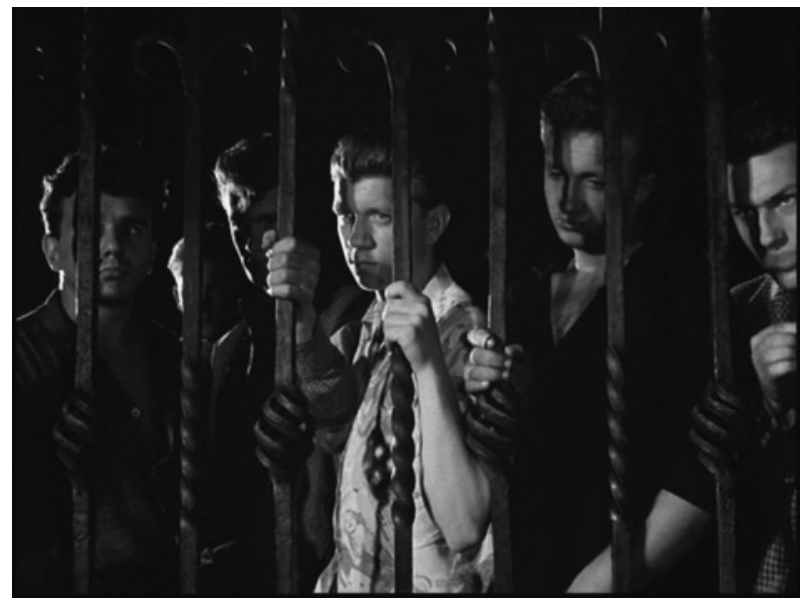
plinarnej i reprymendzie, której udzielił Polańskiemu dziekan Jerzy Bossak. Opiekun etiudy, Andrzej Munk wyraził wątpliwość, czy jest to autentyczny dokument, a jednocześnie nazwał go „kawałem w złym guście", umiejętnie broniąc w ten sposób i osłaniając swego podopiecznego.

„Nawet w bardzo krótkich filmach można opowiedzieć w przekonywający sposób jakąś historię z początkiem i końcem” - uważał w latach pięćdziesiątych pewien młody człowiek, który jako student reżyserii już wkrótce miał udowodnić, że naprawdę można. Niewątpliwą zaletą i wielkim atutem studenckiej etiudy Polańskiego jest nośna i niezmiernie atrakcyjna, również dla współczesnego widza, konstrukcja tego utworu. Składa się on z kilku zręcznie zainscenizowanych, soczystych epizodów i pewnej liczby pobocznych obserwacji, powiedzmy umownie, obyczajowych. Obserwacje te pełnią w strukturze całości funkcję narracyjnych dygresji (banda chuliganów, elegant w ciemnym garniturze i z parasolem sprawdzający swój wygląd przed lustrem, zabójstwo nad strumieniem, pijak zmagający się ze stromymi schodami, chłopiec na plaży układający za pomocą wiaderka babki z piasku etc.).

Postawmy sobie w tym miejscu elementarne pytanie: o czym właściwie jest ten film? I kwestia druga, ściśle z pierwszą powiązana: czy zaprezentowana w nim opowieść ma charakter całkowicie fikcjonalny, wymyślony i nierealistyczny, czy też może zawiera ona jednak w sobie pierwiastek jakiegokolwiek realizmu?

Niełatwo odpowiedzieć jednoznacznie na oba powyższe pytania. Dwaj ludzie z szafa kryją w sobie osobliwy paradoks. Z jednej strony, mamy w nich epizody aktorskie od A do Z inscenizowane przed kamerą, z drugiej - scenki uliczne, w których fikcja bezpośrednio 
przenika się z rzeczywistością. Za sprawą przemyślnej reżyserii, jedno wynika z drugiego i nie sposób tych dwóch żywiołów - podobnie jak elementu opisu i elementu opowiadania - od siebie rozłączyć i od-

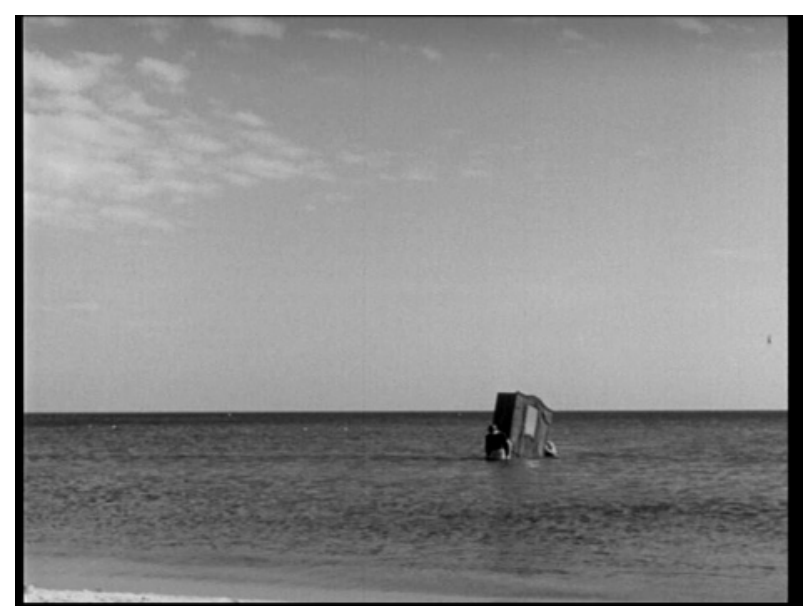

Dwaj ludzie z szafa [I ujęcie] dzielić, na drodze anatomicznego wypreparowania tkanek. Może zatem posłużyć się analizą samej fabuły?

Niestety, tu także czeka nas ostatecznie zawód i fiasko. Zastosowanie klucza fabularnego do tej, co tu dużo mówić, ekscentrycznej opowiastki nieuchronnie musi skończyć się interpretacyjnym niepowodzeniem. Nie da się jej racjonalnie wyjaśnić. Dlaczego tak się jednak dzieje i dlaczego ów na ogół przydatny klucz zawodzi w przypadku próby dotarcia do głębszych znaczeń tego zadziwiająco pięknego filmu? Otóż dlatego, że jego fabuła - rozumiana jako ciąg wydarzeń ekranowych układających się w spójny ciąg umotywowanych i logicznie połączonych z sobą przyczyn i skutków - została przez autora przemyślnie zdekonstruowana i sprowadzona przez niego do absurdu. W jego filmie wszystko toczy się na pozór logicznie, w gruncie rzeczy jednak całość tej konstrukcji opiera się na całkiem innej zasadzie, która $\mathrm{z}$ fabułą jako taką ma niewiele wspólnego.

Już pierwsze ujęcie Dwóch ludzi z szafą ukazujące tytułowy duet dziwaków, która wynurza się na naszych oczach w słoneczny dzień z morza, niosąc w stronę pustej plaży kłopotliwe brzemię, kwestionuje zasadę rzeczywistości, w którą warto zainwestować własną wiarę. Dasz wiarę, że istnieją gdzieś na świecie tacy dwaj? Nie dam wiary, ale zaintrygowany ich istnieniem i zaskoczony tym, że się ni stąd, ni zowąd nagle pojawili, z zaciekawieniem obejrzę opowiadaną przez autora historię. Coś takiego nakręcił dwie dekady wcześniej ojciec polskiej awangardy filmowej Stefan Themerson, realizując równie ekscentryczną jak Dwaj ludzie z szafa - etiudę-przypowieść zatytułowaną Żywot człowieka poczciwego (1937).

Inspirowana w pewnym stopniu Antraktem René Claira i Francisa Picabii (1924), dziesięciominutowa miniatura filmowa autorstwa Stefana i Franciszki Themersonów, z muzyką Stefana Kisielewskiego, jest perełką w dorobku europejskiej sztuki filmowej lat trzydziestych. Bogactwo inwencji tego krótkiego filmu wprawia w zdumienie do dnia dzisiejszego. Bohater, zaskakujące widzenie świata, dowcip, przewrotna lekkość narracji, nonkonformistyczne przesłanie (prawo do życia w odmienny niż inni sposób) - wszystko to wydaje się na wskroś współczesne, choć nakręcone zostało ponad siedemdziesiąt lat temu.

Żywot człowieka poczciwego nosi intrygujący podtytuł: Humoreska irracjonalna, $w$ której każdy snadnie poetyckie możliwości czło- 
wieka poczciwego obejrzeć może. Podtytuł ten opatrzony został dodatkowo odautorską apostrofą dedykowaną widzowi: „Człowiek Poczciwy prosi P.T. Publiczność aby jego lirycznego odskoku od rzeczywistości nie brała za bezsensowną ekstrawagancję.” W filmie Themersonów pojawia się jeszcze jedno zaczepne motto: „Nie będzie dziury w niebie, jeśli pójdziesz tyłem.”

Na tym nie koniec artystycznych analogii i związków Żywota poczciwego człowieka z etiudą Dwaj ludzie z szafa. Odkrywamy tu nie tylko przejęty i zacytowany wprost znany rekwizyt w postaci szafy z lustrem, ale również tandem niosących ją przez świat ludzi. Nie odbiera to $\mathrm{w}$ niczym oryginalności etiudzie Polańskiego, przeciwnie, pokazuje właściwą jej siłę przekształcenia. W pierwszym z tych filmów autor, aby unaocznić różnicę między swoim bohaterem a resztą świata, kazał mu chodzić wstecz. Dwadzieścia lat później, pełnemu inwencji studentowi wystarczyła szafa. Gdziekolwiek ci dwaj się z nią pojawiają, okazują się obcy i nie ma dla nich miejsca.

Widać jednak zasadniczą odmienność tonacji obu utworów. Z gatunkowego punktu widzenia wiele się zmieniło: humoreska Themersonów w ujęciu Polańskiego stała się makabreską. Istota konfliktu pozostała jednak ta sama: w centrum zainteresowania twórców tu i tam znajduje się bezmyślnie wypraszana i niszczona przez ogół odrębność jednostki ludzkiej. To właśnie ona stanowi naczelną wartość zarówno Człowieka poczciwego, jak i Dwóch ludzi z szafą, czyniąc z obu filmów hymn w obronie nonkonformizmu. Nasuwa się jednak wątpliwość, czy Roman Polański znał ten kapitalny przedwojenny polski film awangardowy? - Odpowiedź na to pytanie jest za sprawą samego reżysera najzupełniej jednoznaczna. Z całą pewnością, znał. Etiuda Themersonów znajdowała się w zbiorach filmowych Szkoły i była wyświetlana studentom.

Oryginalność i własna inwencja Polańskiego polega na tym, że wychodząc od formy zaprojektowanej przez innego artystę, nadał jej nowy sens i całkiem odmienną artystyczną ekspresję. Zachował się przy tym podobnie jak jazzman, który przejmuje od swego poprzednika melodię, temat, atrakcyjny standard. Przejmuje po to, by zagrać go po swojemu. Autor Dwóch ludzi z szafq wziął więc od poprzedników tylko kilka nut, kanwę, punkt wyjścia, zarys pewnego artystycznego konceptu i nic poza tym. Przede wszystkim jednak rozwinął pomysł, wymyślając od nowa swoich bohaterów. Kim są? Skąd się wzięli? Skąd i dokąd zmierzają? Po co dźwigają z sobą wielką i ciężką szafę? Co wydarzyło się wcześniej, zanim ich ujrzeliśmy? Do jakiej rzeczywistości należą? I czy ta, w której się znaleźli (w domyśle nasza własna rzeczywistość), pozostaje tak bardzo nie do zniesienia, że trzeba w końcu od niej uciec, zanurzając się na powrót razem z szafą w morskiej toni?

Sprawa realizmu wczesnych filmów Romana Polańskiego jest kwestią kluczową dla przestudiowania metody twórczej, jaką krok po kroku wypracowywał zarówno podczas studiów, jak i po studiach. Nic 
dziwnego, że poświęcimy jej cały następny rozdział zatytułowany „Realizm Polańskiego”. Już teraz odsyłam do niego Czytelników. Zanim to nastąpi, spróbujemy najpierw zajrzeć za kulisy produkcji jego słynnej etiudy, zaczynając - dość nietypowo - od końca, czyli muzyki skomponowanej do filmu przez Krzysztofa Komedę.

Ktokolwiek widział choćby raz Dwóch ludzi z szafa, ten pamięta nie tylko rozmaite sceny i obrazy z tego filmu, lecz również, a może przede wszystkim, kapitalną muzykę napisaną i wykonaną przez sławnego jazzmana $z$ udziałem jego sławnego już wtedy Sekstetu.

Jak doszło do spotkania Polańskiego z Komedą i ich pierwszej filmowo-muzycznej współpracy? Niezwykłą intuicją wykazał się młody kibic Sekstetu Komedy, 19-letni Jerzy Skolimowski. Od początku uważał i twierdził $\mathrm{z}$ absolutną pewnością, że muzyka napisana przez lidera tego zespołu do etiudy Polańskiego okaże się wspaniała. To on najpierw, w końcu lata 1957, podsunął Polańskiemu pomysł, by ten zwrócił się do Komedy, a następnie doprowadził do pierwszego roboczego spotkania ich obu.

Co tu dużo mówić, propozycja, z jaką zamierzał zwrócić się do Komedy Polański z punktu widzenia kogoś z rodzimej branży kompozytorskiej nie należała do poważnych. Chodziło przecież napisanie muzyki nie do pełnometrażowego kinowego filmu fabularnego, tylko do krótkiego warsztatowego ćwiczenia, skromnej studenckiej etiudy. Rzecz zresztą nie w tym, że była to forma miniaturowych rozmiarów, lecz w tym, iż etiudy realizowane wówczas w Łodzi z reguły (choć zdarzały się od niej wyjątki) wykorzystywały gotową muzykę nagrywaną na ścieżce dźwiękowej w charakterze ilustracji. Taki panował wtedy niepisany zwyczaj i taki był powszechnie obowiązujący standard.

$\mathrm{W}$ grę wchodził więc swoisty precedens. Wcześniej muzyki oryginalnej, a już tym bardziej muzyki jazzowej, do ćwiczeń warsztatowych wykonywanych przez studentów łódzkiej Szkoły Filmowej z zasady nie komponowano. Któż zresztą miałby to robić? Udział szanującego się kompozytora w takim jak to, całkiem „niepoważnym” przedsięwzięciu narażał go na despekt bądź śmieszność. Jednak Komeda skierowaną do niego propozycję po obejrzeniu materiałów przyjął. Co więcej, zajął się nią niezwykle poważnie.

Wspaniały temat przewodni, który znamy z filmu Dwaj ludzie $z$ szafą, był jedną z pierwszych kompozycji kiedykolwiek dotąd przez niego napisanych. Według relacji Zofii Komedy i Jana Ptaszyna Wróblewskiego, temat powstał kilka miesięcy wcześniej w Poznaniu, podczas przerwy w próbie zespołu i w ciemnościach (stróż, którego przekupili, aby móc ćwiczyć, zgodził się udostępnić im salę $\mathrm{z}$ fortepianem pod warunkiem, że nie będą palić światła). Krzysztof improwizował, grając po ciemku, a Ptaszyn zapisywał nuty skomponowanej przez niego melodii w świetle na korytarzu.

Opracowany na nowo utwór posłużył jako materiał dla filmu Polańskiego. Nagranie muzyki do filmu Dwaj ludzie z szafa z udziałem: kompozytora oraz Jerzego Miliana, Jana Ptaszyna Wróblewskie- 
go, Zdzisława Brzeszczyńskiego, Józefa Stolarza i Jana Zylbera odbyło się jesienią 1957 roku w studiu nagrań przy ulicy Łąkowej w Łodzi. Oba wykorzystane w niej tematy stały się z biegiem czasu powszechnie znanymi standardami muzyki filmowej. Rezultat debiutanckiej pracy Komedy dla kina okazał się rewelacyjny. Polański nic nie przesadza, mówiąc, że bez niej nie byłoby tego filmu. Podobnego zdania jest Agnieszka Osiecka, pisząc na kartach Szpetnych czterdziestoletnich: „Obraz Polańskiego byłby martwy i płaski, gdyby nie muzyka. [...] Jest w tej muzyce coś, co można nazwać sumą nadziei i rozczarowań, sumą uniesień i upadków naszego pokolenia.”[ [4]

Warto sobie w tym miejscu uświadomić rzecz niby dobrze znaną, ale przecież niedocenianą, mianowicie fakt, że to właśnie możliwość komponowania dla filmu uczyniła z Krzysztofa Komedy znanego i wziętego kompozytora. Wcześniej, to znaczy przed napisaniem muzyki do Dwóch ludzi z szafą, skomponował on zaledwie parę utworów. Sukces filmu Polańskiego przyniósł równocześnie pierwszy kompozytorski sukces Komedzie i od tego momentu jego twórcza aktywność na tym polu nabrała wielkiego rozmachu.

Światowa kariera etiudy Dwaj ludzie z szafą to temat zasługujący na osobne zbadanie. Jej twórcy początkowo wcale nie byli pewni swego. W najlepszym razie widziano w niej nieszkodliwe, ekscentryczne dziwactwo, skądinąd pasujące do obiegowej opinii kursującej w środowisku na temat jego twórcy. Nie ulega zresztą wątpliwości, że był to pomysł tyleż ambitny, co szalony. Według relacji samego autora, momentem zwrotnym stała się nieoczekiwana szansa wysłania filmu na ogłoszony właśnie konkurs filmów eksperymentalnych zorganizowany w Brukseli z okazji Światowej Wystawy Expo'58. Dowiedziawszy się o tym, Polański udał się na rozmowę do ówczesnego dziekana Wydziału Operatorskiego, prof. Stanisława Wohla i oświadczył, że wspólnie ze swym kolegą ze studiów, operatorem Maciejem Kijowskim nakręci film, który zdobędzie prestiżową nagrodę za granicą.

Mądrego pedagoga nie przestraszył ani buńczuczny ton wyzwania rzuconego światu przez ambitnego studenta, ani nawet niezwykle słony jak na studenckie ćwiczenie kosztorys realizacji etiudy, która miała zostać nakręcona nad morzem, w Trójmieście, na dodatek w środku wczasowego sezonu. Polański dołączył do swego podania scenariusz i sporządzony ujęcie po ujęciu scenorys całości. Było to absolutnie nieodzowne, ponieważ film od samego początku miał być, o czym mało kto dziś pamięta, etiudą nie reżyserską, lecz operatorską. Mimo wysokich kosztów całego przedsięwzięcia, odważny dziekan skierował projekt do produkcji i latem 1957 roku ekipa Polańskiego ruszyła na Wybrzeże.

W tym miejscu oddajmy głos samemu Polańskiemu, który w swoich spisanych dziesiątki lat później wspomnieniach tak oto

[4] A. Osiecka, Szpetni czterdziestoletni. Łódź 1985,

cyt. s. 73. 
opowiadał o perypetiach towarzyszących realizacji Dwóch ludzi z szafa:

Czyhałem stale na możliwość zrobienia filmu poza obowiązującym programem szkoły. Maciek Kijowski, student wydziału operatorskiego, miał nakręcić jakąś etiudę, więc przekonałem go, żeby przyznaną mu taśmę wykorzystał do zrobienia pełnej krótkometrażówki, którą ja bym wyreżyserował, tak jak to zrobiłem $\mathrm{z}$ Todorowem na pierwszym roku studiów. [...] Zdjęcia postanowiliśmy robić w Sopocie (a także w Gdańsku - dopisek mój, M.H.). Wraz z Andrzejem Kostenką, któremu powierzyłem funkcję asystenta, przeżywaliśmy nie lada emocje, czując, że stajemy się ośrodkiem zainteresowania. Tłum letników sprawiał, że zdjęcia na ulicy z przyjemności przerodziły się w koszmar. Przewidziane w planie dziesięć dni wydłużyły się do trzech tygodni. Jako gorący zwolennik obsadzania ról zgodnie z typem fizycznym postaci i zdecydowany przeciwnik angażowania aktorów zawodowych, dwie główne role powierzyłem kolegom, którzy w sposób absurdalny różnili się wyglądem. O to mi właśnie chodziło: mały Kuba Goldberg z pomarszczoną twarzą i łysiejący student czwartego roku Henryk Kluba.

Niemal cała ekipa zagnieździła się w wynajętym, ciasnym mieszkaniu i z zapałem zabrała się do pracy. Początkowo atmosfera była pełna entuzjazmu. Potem moi dwa główni aktorzy mieli coraz wyraźniej dosyć taszczenia szafy. Obaj mieli własne zobowiązania i nie mogli już doczekać końca. [...] Mimo opóźnienia w planie nie było mowy, żeby szkoła przyznała dodatkowe fundusze. Wprawdzie udało się nam zatrzymać wózek $\mathrm{z}$ kamerą, ale za nasze posiłki musiałem płacić z własnej kieszeni. Po zakończeniu zdjęć zawiozłem owoc naszych trudów do Łodzi i zabrałem się do montażu[5].

Kilka tygodni później film był gotowy. Profesorowie Stanisław Wohl i Jerzy Bossak po obejrzeniu D wóch ludzi z szafa pomogli zgłosić dzieło swych studentów do brukselskiego konkursu $\mathrm{z}$ ominięciem procedury uprzedniego zatwierdzenia przez odpowiednie czynniki w Ministerstwie Kultury i Sztuki. Polański starannie zapakował pudełka z taśmą i pocztą lotniczą wyekspediował przesyłkę do Belgii. Wiadomość, jaka wkrótce potem nadeszła do kraju, zelektryzowała nie tylko środowisko samych filmowców, lecz całą Polskę, stając się jednym z największych sukcesów polskiego kina lat pięćdziesiątych za granicą. Decyzją Jury etiuda zdobyła na Festiwalu w Brukseli Brązowy Medal. Złoty Medal przypadł znakomitej animacji Jana Lenicy i Waleriana Borowczyka Dom.

Studencka etiuda zrealizowana przez słuchacza łódzkiej Szkoły Filmowej nagrodzona na międzynarodowym konkursie filmów eksperymentalnych. Pełne zaskoczenie, bomba i sensacja. Coś takiego byłoby nie do pomyślenia jeszcze pięć czy sześć lat temu! Roman Polański i jego koledzy sprawili, że dzięki ich nowatorskim pracom $\mathrm{w}$ drugiej połowie lat pięćdziesiątych całkowicie zmienił się obowiązujący dotychczas socrealistyczny paradygmat ćwiczenia warsztatowego z kamerą. Dotąd powstawały one wyłącznie na potrzeby Szkoły.

[5] R. Polański, op.cit., ss. 114-116. 
Nie miały być niczym więcej niż zadaniem operatorskim bądź reżyserskim wykonanym na zaliczenie.

To Polański był tym, który pierwszy wyprowadził studencką etiudę filmową poza mury akademii i sprawił, że mogła ją obejrzeć szeroka publiczność. To dzięki niemu liczyć się będzie w tej Uczelni aż po dzień dzisiejszy nie schematyzująca poprawność, lecz sztuka filmowa bez cudzysłowu. Sztuka, której przysługują takie atrybuty, jak: własny charakter pisma, oryginalny wyraz, odkrywczość i niepowtarzalność. Wartość artystyczną dzieła Polańskiego trafnie podsumował po latach Henryk Kluba, mówiąc: „Cokolwiek by jednak o tym wszystkim nie myśleć, film Dwaj ludzie z szafą stał się wizytówką Szkoły na całe dziesięciolecia."[6]

W rozdziale tym zajmiemy się zagadnieniem o znaczeniu kluczowym dla twórczości Polańskiego. Przedmiotem naszych rozważań nie stanie się wyłącznie sama kwestia realistycznego bądź też nierealistycznego obrazu świata w Dwóch ludziach z szafą. I nie chodzi tylko o ten jeden film, choć właśnie on posłuży nam za przykład, dostarczając cennego materiału do analizy. Spróbujemy jednak uogólnić poczynione na tym przykładzie spostrzeżenia. Będzie nas tu interesował obecny w każdym z filmów nakręconych przez tego twórcę - autor widmo, byt umowny i wirtualny, konstrukt semiotyczny możliwy do odczytania nie z jednego, lecz z całej serii dzieł. Polański - realistą? A jakże!

Realizm - nie tylko filmowy, ale także malarski, teatralny czy literacki - występuje w sztuce XIX i XX wieku w wielu rozmaitych odmianach, przez co stanowi pojęcie wieloznaczne i często mylące. Realizm filmów Romana Polańskiego nie jest bynajmniej nudnym, scholastycznym zagadnieniem, ani jeszcze jednym tak zwanym problemem akademickim. To coś bardziej ogólnego i zarazem frapująco konkretnego. Zawiera się bowiem w tym pojęciu nie wymyślna abstrakcja, lecz czyjeś indywidualne spojrzenie na świat i konkretna praktyka twórcza w jej poszukiwaniach, kolejnych fazach, wieloletnim rozwoju i nieustannych przemianach rozgrywających się na przestrzeni dziesięcioleci: od Morderstwa (1957) do Autora widma (2010).

Rozwiązania intrygującej zagadki, jaka przed nami stoi, nie ułatwia nam też sam reżyser. W swoim komentarzu do genezy „Dwóch ludzi z szafą", odnosząc się krytycznie do etiud kręconych przez kolegów, formułuje on własny pogląd na ten temat w następujący sposób:

Moim zdaniem, należało zapomnieć o realizmie. Chociaż fascynował mnie surrealizm, chciałem, żeby film zawierał pewne przesłanie. Krótkometrażówka, która pragnąłem nakręcić, miała więc być poetycka, alegoryczna i zarazem zrozumiała.

Do tych wniosków doszedłem intuicyjnie, nie wynikały wcale z przemyśleń. Pierwsze obrazy, jakie zarysowały się w mojej wyobraźni, były rów-

[6] Filmówka. Powieść o łódzkiej Szkole Filmowej,

op. cit., s. 118. 
nie irracjonalne: dwaj mężczyźni wyłaniają się z morza, taszcząc fortepian. Była to niedorzeczność, sytuacja absurdalna, w stylu naszych zwariowanych, szkolnych wygłupów. Poza dźwiganiem fortepianu mężczyźni nie robią nic nadzwyczajnego, ot, próbują wejść do restauracji, wsiąść do tramwaju, wynająć pokój w hotelu. Są to osobnicy komiczni i nieszkodliwi, ale ich dziwne brzemię sprawia, że wszędzie są niepożądani i zewsząd przepędzani. Pomysł z fortepianem wziął się prawdopodobnie $\mathrm{z}$ naszych dziecinnych zabaw z Winowskim (Piotr Winowski - szkolny kolega Polańskiego z okresu dzieciństwa - M.H.). Doszedłem do wniosku, że jedyny problem przedstawia sam fortepian: może wywołać niewłaściwe, symboliczne skojarzenia, że dwaj mężczyźni to artyści odrzuceni przez filistrów, podczas gdy ja miałem na myśli alienację bardziej ogólną. Zdecydowałem się na staroświecką szafę z lustrem, jaką można znaleźć w podrzędnych hotelach na całym świecie.[7]

Otóż to, tędy droga. Autor cytowanych słów deklaruje co prawda expressis verbis, że odrzuca „symboliczne skojarzenia” Cytowana uwaga odnosi się jednak nie do filmu jako całości, lecz do fortepianu jako instrumentu i obiektu szczególnie mocno naznaczonego symbolicznie w historii kultury polskiej. Jeśli więc nie symbol, a przecież w całym tym filmie chodzi o coś niedosłownego i umownego, pozostaje jeszcze alegoryczność, bo ona $\mathrm{z}$ istoty swej wymaga głębszego odczytania nie wprost owej „alienacji bardziej ogólnej”, o której mówi Polański. Tak czy inaczej, szukając dla odbioru swojej krótkometrażówki najlepszego z możliwych klucza, w pierwszej kolejności charakteryzuje ją jako „poetycką”. Dopowiada przy tym, iż powinna być „zarazem zrozumiała".

Zanotujmy w pamięci tę, jak się zaraz okaże niezmiernie przydatną, odautorską sugestię: poetycka i zarazem zrozumiała. Pierwszą scenę Dwóch ludzi z szafą można potraktować jako „poetycką”, ale nie sposób uznać za „zrozumiałą”. Jak powiada w cytowanym wyżej autokomentarzu sam reżyser: „dwaj mężczyźni taszczący fortepian to niedorzeczność”. Dokładnie to samo można o dwóch mężczyznach z filmu niosących ciężką szafę i wychodzących z morza na bałtycką plażę. Zaprezentowana na ekranie sytuacja, której jesteśmy świadkami, wykracza daleko poza logikę przyziemnej, potocznie rozumianej „prawdziwości” i całkiem nie mieści się w ramach jakiegokolwiek życiowego prawdopodobieństwa.

Co innego, druga ze scen tej etiudy dziejąca się na plaży. Szafa zostaje postawiona na piasku, a dwaj tragarze uwolnieni od kłopotliwego ciężaru zabierają się - uwaga! - za usuwanie wody z uszu i wyżymanie mokrej czapeczki. Czynności, które można uznać za uniwersalnie zrozumiałe, są bowiem dobrze znane każdemu z nas, należąc do naszego potocznego doświadczenia. Zauważamy też sposób ubioru obu mężczyzn. Jeden $z$ nich ubrany jest wakacyjnie (marynarski T-shirt), a drugi nosi przepisowy roboczy strój do pracy fizycznej, czyli - nawiązujące do ubioru mechanika, montera czy robotnika 
(Charlie w Dzisiejszych czasach!) - farmerki na szelkach (tzw. ogrodniczki).

W drugiej z opisanych scen, w ciągu kilku chwil dokonuje się na naszych oczach swego rodzaju naturalizacja obu właśnie poznanych bohaterów. Moment wcześniej całkiem obcy, stają się na naszych oczach dziwnie znajomi, „swoi” i poniekąd bliscy. Polański konsekwentnie dogląda i pilnuje przemieszczającego się to w jedną, to w drugą stronę układu sił na zbudowanej przez siebie równoważni, zręcznie odnajdując dla niej nieodzowny balans. Jeszcze przed chwilą zaskakująco od nas różni, odmienni, ekscentryczni i nie z tej ziemi, teraz stają całkiem realni i bliscy. Wydają się częścią nas samych, tyle że przeniesionych $\mathrm{w}$ inny wymiar dzięki magii kinowego spektaklu.

Reżyser umiejętnie zaciera granice między zmyśleniem a realnością,

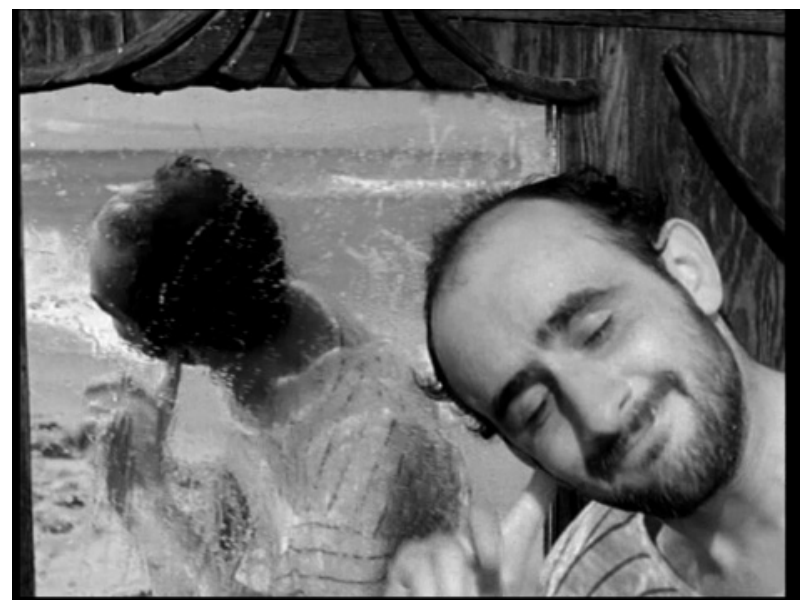
kreując umowną rzeczywistość dzieła sztuki, w którym jest miejsce i na jedno, i na drugie. Dwaj odmieńcy okazują się żywymi zwykłymi ludźmi.

Dualizm prawdy i zmyślenia, jawy i snu, obiektywnego i subiektywnego pierwiastka ekranowego obrazu świata - będzie odtąd stale dawał o sobie znać w kolejnych scenach i na różnych poziomach tej opowieści. Zderzenie obu scen wprowadza zamierzoną przez reżysera metamorfozę: ci dwaj nie są wcale tacy obcy, jak nam się w pierwszej chwili zdawało, kiedy ze zdumieniem obserwowaliśmy ich wynurzenie (resp. nieoczekiwane wejście w świat, który znamy).

Bohaterowie etiudy Polańskiego są parą ludzi „nie z tej ziemi”. Stanowią temat poetyczny i niezwykły na tle swego otoczenia. Obaj należą i jednocześnie nie należą do tego świata. Problemem jest już sama alternatywa ich istnienia. Ma ono w sobie coś dziwnie niepokojącego: drażniącego i urzekającego zarazem. W pierwszej chwili ich istnienie wydaje się arkadyjskie, idylliczne, lekkie jak morska pianka, by za chwilę ustąpić miejsca nieznośnemu ciężarowi tutejszej realnej egzystencji. Skonfrontowani z pospolitymi realiami i brutalnością otoczenia, w którym się znaleźli, starają się znaleźć dla siebie miejsce i obronić własny (czytaj: odmienny) sposób życia.

Themersonowski pierwowzór Żywota człowieka poczciwego" zostaje przez Polańskiego nie tylko przywołany i wykorzystany na nowo, ale i uwspółcześniony. Tym samym młody autor wchodzi w pewną rywalizację z dziełem swego poprzednika, zachowując jednak własne spojrzenie i odrębność. Warto zwrócić uwagę zarówno na to, co łączy, jak i co dzieli oba filmy. W obu liczy się odmienność, inność i własna droga (resp. indywidualny sposób na życie). Twórca Dwóch 
ludzi z szafa, podobnie jak Themersonowie, co rusz zderza znaną widzowi prozaiczną codzienność z zauważalnym niedostosowaniem swoich bohaterów. Nie wystarcza mu jednak samo tylko chodzenie do tyłu i nieprzypadkowo w ogóle rezygnuje z ponownego wykorzystania tego motywu.

Dlatego w przypadku bohaterów „Dwóch ludzi z szafą” nie należy mówić jedynie o ich odmienności (uprzedzał o tym w autokomentarzu sam Polański). W porządku utworu artystycznego ci dwaj wraz z ich niewygodnym rekwizytem, szafą, okazują się nie tyle znakiem czegoś odmiennego, ile alegorią różnorodności. Nie są oni nierealni, nie są też dziwakami, odmieńcami, outsiderami z wyboru. Stają się natomiast alternatywą tego, co jest - niezwykle sugestywnym ekranowym wyobrażeniem i ucieleśnieniem różnorodności. Chcą żyć po swojemu; to wystarczy, by spotkali się z agresją i zostali odrzuceni przez zuniformizowane otoczenie. Notabene, trzeba w tym miejscu przywołać inny znakomity polski film eksperymentalny z okresu Października dotykający tematu różnorodności, nakręcony dokładnie w tym samym czasie. Chodzi o animowaną etiudę Waleriana Borowczyka i Jana Lenicy Był sobie raz... (laureata Złotego Lwa św. Marka w kategorii filmu eksperymentalnego na MFF w Wenecji, 1957).

Mowa była o nieustannym poszukiwaniu równowagi między fikcją a rzeczywistością i swego rodzaju reżyserskim balansie, który w etiudzie Polańskiego i Kijowskiego co rusz daje o sobie znać zarówno $\mathrm{w}$ inscenizacji poszczególnych scen, jak i w przebiegu narracji. Warto więc sięgnąć po inny przykład, w którym to, co prozaiczne, zyskuje nagle wymiar par excellence poetycki. Oto scena na sopockim

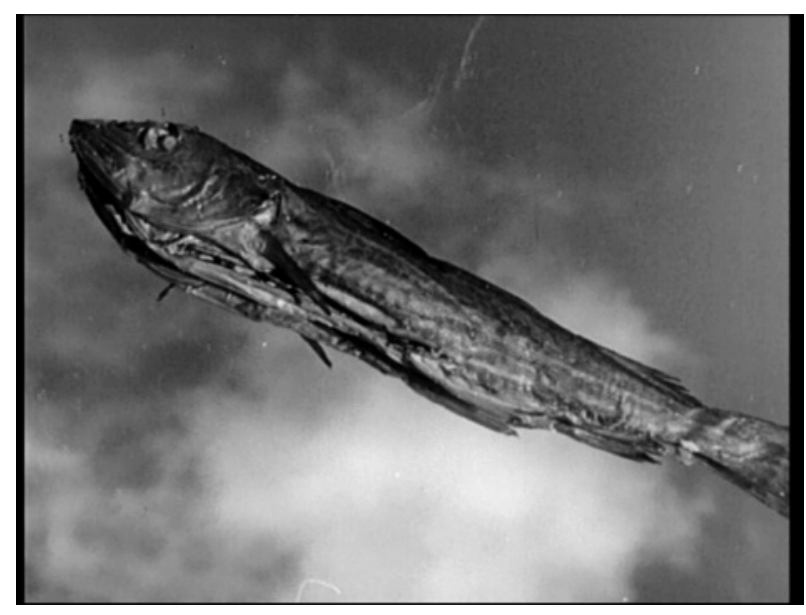
molo. Dwaj bohaterowie siedzą na położonej plecami szafie i pożywiają się. W ich niebogatym jadłospisie tego ranka pojawia się jakże prozaiczny wędzony dorsz. Wystarczy jeden zręczny zabieg oparty na iluzji odbicia w lustrze szafy i naszym oczom ukazuje się - pamiętny metaforyczno-symboliczny obraz z Dwóch ludzi z szafą ryba płynąca w chmurach.

Mamy tu scenę będącą odwróceniem - swoistym rewersem wobec poprzednio opisanego awersu. $\mathrm{W}$ pierwszej z przywołanych scen zaskakujący obraz artystyczny stawał się

Dwaj ludzie z szafa [odbicie ryby w lustrze szafy] na naszych oczach rzeczywistością. Tutaj prozaiczna rzeczywistość wędzonego dorsza zamienia się w urzekająco piękny obraz artystyczny. Cóż za niezwykła metamorfoza! Kunszt reżyserski młodego filmowca daje o sobie znać nie tylko w jego dojrzałych dziełach nakręconych w warunkach produkcji profesjonalnej, lecz dużo wcześniej: w serii owych skromnych studenckich etiud, których realizacja umoż- 
liwiła mu krok po kroku nie tylko zbudowanie reżyserskiego warsztatu, ale i opracowanie własnej metody twórczej.

Odczytanie realizmu w twórczości Romana Polańskiego nie jest sprawą łatwą. Pierwiastek, czy jak kto woli aspekt, realistyczny stale obecny w jego filmach nie polega bynajmniej na mechanicznym kopiowaniu wyglądów świata. Jako inscenizator i reżyser, nie stara się on niczego wiernie przenosić na ekran ani mechanicznie odwzorowywać za pomocą kamery. Inscenizując poszczególne ujęcia i sceny, Polański-realista na każdym kroku wysyła w naszą stronę rozmaite sygnały pozaekranowej obecności realnego świata i odwołuje się zarówno do jego własnej, jak i zbiorowej pamięci.

Intrygujący realizm Dwóch ludzi z szafą i innych filmów tego reżysera opiera się bardzo konsekwentnie na poszerzonym spojrzeniu na rzeczywistość. Poszerzonym, to jest takim, w którym jest miejsce na coś więcej - na świat alternatywny (czytaj: otwarty na różnorodność). Świat, w którym jest dość przestrzeni artystycznej nie tylko na przyziemne i prozaiczne odzwierciedlenie sfilmowanego hic et nunc Gdańska oraz Sopotu z lata 1957, ale ponadto również na brawurowe wykroczenie (wybryk) artysty, który powołuje do życia byt tak nadrealnie-realny, niezwykły, odmienny i samoswój, jak dwaj ludzie z ich nieodłączną szafą.

Istnienie tych dwóch i ich nieoczekiwane pojawienie się wśród nas uzmysławia, iż zwykły, prozaiczny świat, w którym żyjemy, ma także swój inny wymiar. „Są rzeczy na niebie i ziemi, o których nie śniło się waszym filozofom." Owa odmienna od naszej, alternatywna rzeczywistość jest jak muzyka Komedy dobiegająca zza kadru. Nie należy jej traktować jako czegoś obcego i nadnaturalnego. Siła kreacji artystycznej w „Dwóch ludziach z szafą” sprawia, że bohaterowie tego filmu zjawiają się i zaczynają istnieć w polu naszego widzenia całkiem zwyczajnie, pozbawieni atrybutu nadnaturalności. Odkrywając niezwykłość ich istnienia, odkrywamy fenomen możliwości innego niż nasze życia. Tym większy szok egzystencjalny towarzyszy reakcji zaskoczonego widza w momencie spotkania i osobistego zetknięcia z nimi. Autor tej etiudy przywiązuje wielką wagę do urzeczywistnienia poetyckiej fikcji poprzez osadzenie jej w istniejących realiach. Tworząc ją (jak ów chłopiec na końcu filmu ustawiający na plaży setki babek z piasku), dopełnia i wzbogaca otaczającą nas rzeczywistość o jej inny (poetycki) wymiar.

W tym sensie świat na ekranie, który jest mu bliski, musi oprócz kotwicy realności mieć jeszcze w swoim wyposażeniu żagiel poetyckiej wyobraźni. Z jednej strony, istotną cechą sztuki filmowej Polańskiego jest trwałe przywiązanie do konkretu rzeczywistości. $\mathrm{Z}$ drugiej strony, bycie realistą nie zawęża u niego, a wręcz przeciwnie, poszerza wizję ekranowego świata. To, co istnieje, odnajduje swój przenośny ekwiwalent w tym, co mogłoby istnieć. Dlatego możliwe (i realne!) stają się byty tak niezwykłe, jak bohaterowie Dwóch ludzi $z$ szafa. I nie chodzi tu o zbudowanie środkami filmowymi jakiejś 
ekranowej science fiction. Zasada artystycznej autonomii obrazu filmowego leżąca u podstaw jego kunsztu reżyserskiego nie oznacza całkowitego zerwania z tym, co realne. Korelacja między światem, jaki jest, a wyobraźnią artysty uwzględnia w przypadku jego twórczości wzajemne przenikanie i osmozę obu sfer.

Autor Dwóch ludzi z szafą, Ssaków i Noża w wodzie nie ucieka od rzeczywistości, z pokorą traktuje jej twarde realia i nie pretenduje bynajmniej do tego, by stać się prorokiem „czystego kina”. Idea cinéma pure $\mathrm{z}$ całą pewnością nie leży u podstaw jego sztuki. Rzeczywistość i jej filmowe przedstawienie współistnieją, alternują i przenikają się u niego nawzajem.

Realizm w wydaniu Polańskiego - rozumiany tutaj jako pewien powtarzający się wyznacznik i walor integralnie połączony z poetyką zarówno pojedynczych filmów, jak i całej twórczości tego reżysera okazuje się zjawiskiem nader złożonym. To jego własny realistyczny patent, czy jak kto woli, patent na filmowy realizm, rozwijany i modyfikowany w kolejnych utworach.

Realizm w specyficznej odmianie, jaką wypracował Polański, charakteryzuje znaczny stopień oryginalności. Nie sposób o nim powiedzieć, że jako „izm” przypomina inne znane „izmy” artystyczne $z$ rodziny realistycznych. Nie jest więc z całą pewnością naturalizmem, ani neorealizmem. Nie powinien też być utożsamiany $z$ weryzmem. Nie należy go kojarzyć z tak zwanym małym realizmem. Obcy jest mu zarówno fotorealizm, jak i hiperrealizm. I nie uważam, by można go było bez oczywistego uszczerbku wpisać w klasyczne ramy amerykańskiego mimetyzmu filmowego spod znaku kina Grifiitha czy Stroheima.

Szczególna postać realizmu, z jaką mamy do czynienia w filmach Polańskiego, nie jest ani zlepkiem, ani eklektyczną hybrydą złożoną z przywołanych przed chwilą ,izmów”. Zadziwia fakt, iż ich autor potrafi być równocześnie niezwykle konkretny i zarazem poetycki. Określenia „konkretny” i „poetycki” przybliżają nas wprawdzie do charakterystyki filmowego realizmu à la Polański, ale daleko im jeszcze do precyzyjnego wyrażenia jego głębszej swoistości. Nie jest bowiem tak, że reżyser na siłę „poetyzuje” opisywany przez siebie realny świat, tworząc dla przykładu jego balladową alternatywę.

A może to jest nadrealizm? Czy rację mają ci, którzy przypisują tej etiudzie surrealistyczne koneksje? I tak, i nie. Surrealizm (przede wszystkim ten Artaudowski, w mniejszym stopniu Buñuelowski, co było zawsze domeną Wajdy) dostarcza mu od czasu do czasu ożywczych inspiracji. Nie oznacza to jednak bynajmniej, że należy go uważać za epigona surrealizmu. Gdyby przyjąć taką drogę rozumowania, trzeba by przypisać twórczości Polańskiego powinowactwa i rozmaite filiacje również względem wielu innych „izmów”. Skoncentrujmy się jednak ponownie na samym nadrealizmie, odchodząc jednak od jego historycznych kontekstów.

Rzecz w tym, że Roman Polański samą sferę sztuki - a w niej oczywiście także film - uważa za coś nadrealnego. W tym sensie pozo- 
staje wiernym wyznawcą idei artystycznej autonomii obrazu filmowego. Już w swoich najwcześniejszych próbach reżyserskich czyni jednak niezmiernie ważną dystynkcję między: „nadrealnością” jako czymś irrealnym (resp. całkowicie zmyślonym i oderwanym od rzeczywistości, co twórca Dwóch ludzi z szafa zdecydowanie odrzuca) a nadrealnością dzieła sztuki jako szczególną wizją rzeczywistości. I w tym drugim, mniej oczywistym i znacznie bardziej złożonym, sensie pozostaje w swoich filmach konsekwentnie realistą, wykazując - rzecz znamienna - całkowite désintéressement dla kreowania za pomocą środków filmowych irrealnych światów ekranowych. Potrafi więc jeśli trzeba wykreować, dla przykładu, wysoce oryginalną i par excellence fantastyczną, lecz przecież „z życia wziętą” wizję legendarnej Transylwanii, złożoną z elementów sobie znanych, będących pochodną jego własnego doświadczenia.

Jeśli rozpatrzyć tę kwestię głębiej, obrazom filmowym Polańskiego przysługuje atrybut szeroko pojętej nadrealności zarówno w ich aspekcie przedstawieniowym, jak i ontologicznym. Są one czymś nadrealnym i nierzeczywistym (obrazem właśnie, jak obraz malarski w sztuce nowoczesnej). Krótko mówiąc: oglądamy na ekranie nie świat realny, lecz alternatywne względem niego i w tym sensie pozarzeczywiste widowisko filmowe, $\mathrm{z}$ wartką ekranową akcją, zgrabną konstrukcją, aktorami, własnym rytmem, muzyką, zmiennymi punktami widzenia, kunsztownymi figurami montażowymi, klasyczną komopozycją, ściemnieniami, rozjaśnieniami itp. To film i ekranowa fikcja, a nie żadna atrapa pozafilmowej rzeczywistości. Z drugiej strony stają się one jednak - i tak się niezwykle często u niego zdarza - szokująco wręcz realnymi dla widza przedstawieniami znanego mu świata.

Realizm filmów Polańskiego wymyka się prostym kategoryzacjom i domaga się dla siebie indywidualnego rozpatrzenia. Postawmy zatem całą kwestię od nowa i sformułujmy nasze pytanie inaczej: co składa się w gruncie rzeczy na ów realistyczny obraz? Skąd bierze się jego emocjonalna gęstość i sensualna empiria? Z jakiego źródła pochodzi ten stale obecny i na każdym kroku dający o sobie znać realistyczny aspekt tych dzieł?

Jeśli tak postawić pytanie, odpowiedź może być tylko jedna: miarą tego realizmu i jego artystycznym probierzem okazuje się każdorazowo ludzkie doświadczenie. Doświadczenie wspólne, to jest takie, którego posiadaczem jest najpierw autor filmu, dalej wybrane przez niego medium, które je przeżywa i wyraża, czyli aktor. I wreszcie adresat filmu - widz, z którym autor je dzieli. Widz może owo doświadczenie znać z dostępnej mu autopsji i osobiście podzielać je z twórcą, bądź po raz pierwszy w życiu odkrywać w trakcie oglądania filmu. Za każdym razem jednak osiąga ono wyraz ponadjednostkowy i uniwersalny. Uniwersalny w tym sensie, że w grę wchodzi spotkanie i intersubiektywna społeczna wymiana zasobów ludzkiego doświadczenia dokonująca się między autorem a widownią za pośrednictwem komunikatu filmowego. 
Realizm Polańskiego tkwi więc korzeniami głęboko w antroposferze kina. Ma on wyraz niezmiernie sensualny i cielesny. Tworzeniu jego kolejnych ekspresji towarzyszy z reguły wielki wysiłek aktorów. Ale najpierw ekspresja ta - i to jest jej ukryta siła - poświadczona zostaje przez samego twórcę. To on jest jej sygnatariuszem. Czego nie zaznał i osobiście nie doświadczył reżyser, tego nie ma na ekranie. Aby dostrzeżoną przez nas zależność zilustrować, odwołam się w tym miejscu do przykładu w pierwszej chwili dość zaskakującego, a będzie nim wspomniana wcześniej Transylwania, ukazana w Nieustraszonych zabójcach wampirów.

Tę mityczną krainę wykreował twórca filmu z pamięci i z materiału zdumiewająco swojskiego. To Polska i Europa ŚrodkowoWschodnia zimą. Tak jest od pierwszej do ostatniej sceny. Mamy tu sannę jak w Murzasichlu czy Jurgowie, żydowską karczmę prowadzoną przez rodzinę Shagalów, trzaskający mróz za oknem, drewno na opał, wodę noszoną ze studni, luksus gorącej kąpieli w wannie, śnieg po horyzont, wilki i zaspy. Bałwan, którego osobiście lepi Polański, to nasz dobry znajomy: $\mathrm{z}$ węglikami oczu i węglowymi guzikami, marchwiowym nosem, drewnianym wiadrem na głowie zamiast kapelusza i miotłą wetkniętą za pazuchę.

Kto oglądał Nieustraszonych zabójców wampirów dość uważnie, pamięta o wiele więcej takich swojskich szczegółów: oscypki (!), warkocze czosnku zwisające z powały, jazdę za saniami ze stopami na płozach, przemoczone buty Alfreda suszone na piecyku, i góralski „ostrywek”, czyli ostro zaostrzony drewniany kołek (służący tu nie do siana, lecz do przygważdżania wampirów). „Nie namaluję anioła, bo go nigdy nie widziałem” - mawiał Courbet. Polański jako filmowiec nie ma podobnych oporów. Nic u niego nie jest w stu procentach zmyślone, wszystko, co oglądamy, zostało zaczerpnięte z osobistego doświadczenia. Transylwania przedstawiona na ekranie „jak żywa” okazuje się ćwiczeniem z wyobraźni i jednocześnie krainą arcyprawdziwą w szczegółach. Kwintesencję tych zabiegów stanowi kapitalny pomysł reżysera w scenie, w której służąca Shagalów Magda nuci przy pracy Moniuszkowską Prząśniczkę.

Brakuje nam jednak ciągle klucza do wnętrza owego bardzo indywidualnego w swym wyrazie realizmu. Otóż wydaje się, że kłopot z określeniem odmiany realizmu, jaka występuje w filmach Polańskiego, wynika stąd, iż w przypadku jego twórczości prawdziwe kino zaczyna się w momencie, gdy świat ekranowy staje się bytem nadrealnym. Nieprzypadkowo obiektem fascynacji tego artysty - od najdawniejszych etiud studenckich aż po Autora widmo - były zawsze szczególne stany ludzkiego umysłu.

Agresja, mord, psychoza, paranoja, rozdwojenie jaźni, rozpad osobowości, wchłonięcie cudzego „ja”, ekstaza, sen na jawie, marzenie, pociąg seksualny, smak czynu zabronionego, przekraczanie granic tabu, uleganie złu, totalitarny obłęd, przerażenie, dominacja, poniżenie, przemoc i gwałt zadawane drugiemu człowiekowi, wampiryzm, 
lęk, nienawiść, koszmar senny, halucynacje itp. Natrafiamy na nie w poszczególnych scenach, sekwencjach, filmach. Za każdym razem jednak mowa o odmiennych stanach świadomości. Ich niebywale realistyczna prezentacja i kliniczny wręcz opis (Dwaj ludzie z szafa, Wstręt, Dziecko Rosemary, Tragedia Makbeta, Chinatown, Lokator, Tess, Pianista etc.) stanowiły zawsze specjalność tego reżysera. Nota bene, mogłoby to w pewnej mierze tłumaczyć intrygującą alchemię twórczą, jaka połączyła niegdyś kino Polańskiego z muzyką Komedy.

Najwyższy czas postawić pytanie o niepowtarzalny charakter i indywidualne właściwości realizmu, z jakim mamy do czynienia w filmach Polańskiego. Wydaje się, iż realizm ów wynika każdorazowo z osobistego doświadczenia. Nie jest on z pewnością realizmem imitującym, mechanicznie kopiującym wyglądy świata. Jest natomiast realizmem sprawczym, za sprawą którego ekranowa rzeczywistość zostaje nasycona choćby najdziwniejszym, zawsze jednak przejmująco realnym, ludzkim doświadczeniem. Nie trzeba przy tym pytać o immanentną istotę owego realizmu, lecz przyjrzeć się uważnie funkcji, jaką pełni on w danym filmie.

Charakterystyka jego indywidualnych właściwości okazuje się w filmach Polańskiego zmienna i podlega ciągłej ewolucji. Wiąże się jednak ściśle z zadaniem, jakie przypada mu w obrębie danego dzieła filmowego i w procesie komunikowania między jego autorem a widzem. Autor „Dwóch ludzi z szafą” nie jest bynajmniej wyznawcą jakiejś doktryny realistycznej, lecz kimś, kto na własny użytek wypracował sobie własną metodę komunikowania o świecie i głębszego porozumienia $\mathrm{z}$ odbiorcą swoich filmów.

Do makroobrazu świata, $\mathrm{z}$ jakim mamy do czynienia $\mathrm{w}$ twórczości Polańskiego, zdaje się dobrze pasować koncept teoretyczny Guy Deborda, który w „Społeczeństwie spektaklu” pisał, że „cząstkowe ujęcia rzeczywistości scalają się w nową ogólną jedność, tworząc wyodrębniony pseudoświat, przedmiot czystej kontemplacji.” Z jednym wszelako, lecz za to zasadniczym, zastrzeżeniem. Takim mianowicie, że w dziełach tego reżysera nie chodzi o żaden wymyślny „pseudoświat", lecz o świat tout court, w którym rozgrywa się opowieść o losach bohaterów danej historii.

Ów powtarzający się w różnych filmach tego twórcy - na prawach sui generis osobistego lejtmotywu - makroobraz świata jest, ma się rozumieć, autorskim wyobrażeniem - sztucznym ekranowym konstruktem. Takim jednak, na który składają się wybrane przez niego okruchy realności zarejestrowane kamerą i wyświetlone ponownie widzowi jako biernemu, lecz przecież obecnemu współuczestnikowi dziejącego się na jego oczach dramatu. Rzeczywistość w dziełach Polańskiego funkcjonuje na podobieństwo sceny dramatycznej. Świat nie jest immanentnie dobry, ani zły. Pełno w nim rozmaitych konfliktów i napięć. Momentami bywa przyjemny i znośny, kiedy indziej śmiertelnie niebezpieczny dla tych, którzy nie znają jego bezwzględnych reguł i praw. 
Częstym motywem twórczości Polańskiego jest wszechobecny horror rzeczywistości, w której człowiek traci elementarne poczucie bezpieczeństwa, czując się całkowicie bezradny. Akcja ekranowa opiera się tu na rozmaicie aranżowanej ekstrawagancji zaskakujących go zdarzeń. Paranoja, groteskowa przemoc i lęk egzystencjalny są dobrymi znajomymi jego filmów. Realizm filmowego spektaklu wynika ze sposobu przedstawiania. Absurd ukazywanych sytuacji, na jakie natrafiają $\mathrm{w}$ wędrówce przez znaną nam rzeczywistość bohaterowie, znajduje swoje rozszerzenie $\mathrm{w}$ absurdzie świata, $\mathrm{w}$ groźnym chaosie jego codziennych i niecodziennych wydarzeń, sprawek, rozmaitych, mniej lub bardziej przeraźliwych, ludzkich dramatów. Wspólnota egzystencjalnego doświadczenia opiera się na wzajemnej empatii autora i widza.

Nie sposób nie zauważyć, że już we wczesnym stadium rozwoju tej twórczości daje o sobie znać okrucieństwo świata jako jej temat przewodni. Polański doskonale czuje się nie tyle w Artaudowskim teatrze okrucieństwa, co w stworzonym przez siebie ekranowym odpowiedniku tegoż. Okazuje się przy tym artystą bez złudzeń, całkowicie impregnowanym na „hipotezę optymistyczną” w czasach stalinizmu w ZSRR i w stalinowskiej Polsce - bardzo istotną i popieraną przez komunistyczny system wychowania - idée fixe słynnego radzieckiego pedagoga Antona Makarenki. W tym sensie wczesne filmy Polańskiego, z etiudą Dwaj ludzie z szafa na czele, można by określić mianem poematów niepedagogicznych (por. scenę zabijania przez chuliganów kota kamieniem dla hecy i dalsze bestialskie znęcanie się nad martwym zwierzęciem).

Autor Poematu pedagogicznego i Choragwi na wieżach niezachwianie wierzył i sądził, że jednostka zmieni się pod wpływem właściwego wychowania. Autor Dwóch ludzi z szafa pokazuje, że przeobrażenie człowieka jest niemożliwe. Owszem, „oczekiwanie na szczęście jest motorem życia ludzkiego” (Makarenko). Bynajmniej jednak nie może to być szczęście w jego wymiarze abstrakcyjnym. Idzie bowiem zawsze o konkretne doznanie: dostępne, lub najczęściej niedostępne, człowiekowi w danym tu i teraz.

Bohaterowie Dwóch ludzi z szafą, mimo z konieczności szkicowej konstrukcji ich postaci, okazują się prawdziwymi ludźmi z krwi i kości. Są istotami wrażliwymi (czytaj: kruchymi, słabymi i bezbronnymi). Uparcie poszukują swego miejsca pod słońcem i oczekują dla siebie minimum akceptacji oraz tolerancji ze strony otoczenia. Nie są żadnymi outsiderami. Ze swoim indywidualizmem nie mieszczą się tylko w panującym dookoła stylu życia społecznego. Odrzucenie, którego wszędzie doświadczają ze strony bliźnich, jest okrutne i bezwględne. Polega ono na poniżeniu bądź zlekceważeniu, na przemocy fizycznej i pełnym wzgardy okazaniu braku szacunku wobec drugiego człowieka.

Autor, pokazując rzeczywistość taką, jaka ona realnie jest, nie osądza świata, nie żywi żadnych złudzeń na temat dobra rzekomo 
przypisanego i przynależnego naturze ludzkiej. Nie jest jednak cynikiem. Bliska jest mu w tym względzie postawa i filozofia sceptycznego racjonalisty. „Hipoteza optymistyczna” odpada. Zagrożeni w swej egzystencji, sympatyczni lecz całkiem bezbronni odmieńcy, dwaj ludzie szafą starają się jakoś przetrwać i muszą sobie radzić sami, co nie wychodzi im najlepiej.

W nieprzyjaznym - a bywa, że i wrogim - środowisku, do którego trafili, nie ma dla nich miejsca ( $w$ wielkim mieście, $w$ tramwaju, $\mathrm{w}$ restauracji, w hotelu, na ulicy, nawet w ustronnym magazynie beczek, słowem nigdzie). Daremnie próbują wpisać się w obce, na każdym kroku odrzucające ich, nowe środowisko. Charakteryzuje ich nie tylko odmienność, ale i bezdomność. Szukają w należącej zarówno do nas, jak i do nich swojsko-obcej rzeczywistości swego residuum i piède à terre. Poszukują tego minimum daremnie i na próżno. W końcu odchodzą z powrotem do morza, bo wielki świat natury może ich inność pomieścić, świat ludzki nie.

Aby tak się stało, to znaczy by świat ich w naturalny sposób przyjął i zaakceptował takimi, jakimi są - konieczne jest przełamanie istniejących stereotypów myślenia. A ono, jak doskonale wiedzą artyści i nie tylko oni, bywa $\mathrm{z}$ reguły najtrudniejsze.

Ćwiczenie reżysersko-operatorskie pod tytułem Lampa zrealizowali w roku 1959 reżyser Roman Polański i student IV roku Wydziału Operatorskiego Krzysztof Romanowski. Zadaniem warsztatowym, jakie postawili przed sobą w tej krótkiej, niespełna siedmiominutowej etiudzie, było umiejętne zbudowanie, a następnie możliwie najbardziej sugestywne dramatyczne stopniowanie atmosfery tajemniczości i zagadkowości tego, z czym styka się na ekranie widz. Całość cechuje uderzająca jednorodność stylistyczno-kompozycyjna. Filmowa opowieść ma starannie przemyślaną i zaprojektowaną konstrukcję, której podstawową zasadę stanowi umiejętnie stopniowana progresja napięć dramatycznych.

Wbrew rozpowszechnionym obiegowym opiniom, Lampa nie jest od strony gatunkowej typowym filmem grozy. Seria scen, które oglądamy, okazuje się raczej pochodną, czy jak kto woli stylizacją, filmowego horroru zawierającą w sobie nie tyle chwyty typowe dla tego gatunku, co ekscentryczny sztafaż widowiska filmowego z dreszczykiem. Autorowi najwyraźniej nie chodziło o replikę któregokolwiek z klasycznych filmów grozy. Nie miała to być zgrabna, wycyzelowana w szczegółach szkolna imitacja modelowych cech tego popularnego gatunku ani w wersji ekspresjonistycznej, ani w jego odmianie hollywoodzkiej z lat trzydziestych.

Na efekt zamierzonej niesamowitości składa się przede wszystkim miejsce akcji: ciasna i mroczna, skąpo oświetlona jedynie bladym płomieniem lampy naftowej, sceneria małego sklepu z zabawkami. Nota bene, Polański jako autor tej etiudy znów okazał się niemal całkiem zapomnianym dzisiaj prekursorem pewnego toposu: słynny 
horror Rogera Cormana The Little Shop of Horrors powstanie dopiero za jakiś czas, w roku 1960. Utalentowany student łódzkiej Szkoły Filmowej podąża własną drogą. U Polańskiego nie ma ani sadystycznego dentysty, ani monstrualnie groźnej dla otoczenia rośliny

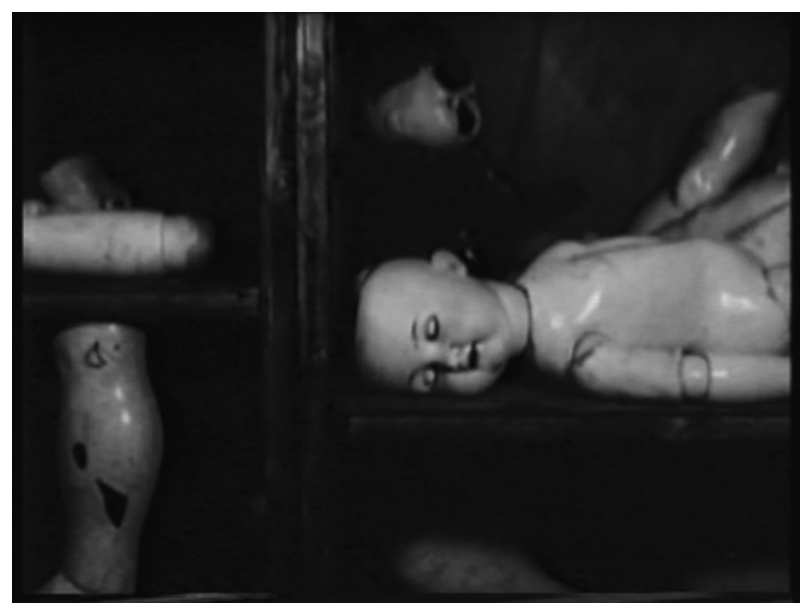
rosnącej w niepowstrzymanym tempie. Umiejętnie eksploruje natomiast wybraną przez siebie mroczną scenerię, dzięki czemu pojawia się w jego filmie szczególnego rodzaju atmosfera zwyczajnej grozy, wydobywana w przemyślny sposób najskromniejszymi z możliwych środkami filmowymi.

Właścicielem dziwnego sklepu stanowiącego scenerię Lampy jest stary człowiek, mozolnie montujący i produkujący kolejne lalki - jako nowe eksponaty swego magazynu kolejno umieszczane na półkach. Mamy tu Lampa [lalki] charakterystyczne rekwizyty, których starannie wypracowana ikonografia przewrotnie nawiązuje do repertuaru po trosze kina ekspresjonistycznego, po trosze malarstwa surrealistycznego, zwłaszcza do obrazów René Magritte’a i Salvadore Dalego. Są więc puste oczodoły figur, gałki oczne leżące na stole brane przez producenta metalowymi szczypcami, dalej peruki, wspomniana lampa naftowa i zegar z kukułką. W pierwszym ujęciu filmu ulicą przed sklepem przejeżdża konna dorożka, która w ostatnim ujęciu mija nas, jadąc w przeciwną stronę. Całość wieńczy scena pożaru sklepu. Języki ognia szybko rozprzestrzeniającego się w drewnianym pomieszczeniu stopniowo obejmują, niszczą i pożerają tajemniczy sklep, który moment wcześniej został zamknięty i zabity deskami przez jego właściciela.

Twórca Lampy postawił nie tylko na wizualną ekspresję filmowych obrazów. Rozbudował również, po raz pierwszy na taką skalę w swej twórczości, warstwę dźwiękową opowieści. Złożyły się na nią: w pierwszej części filmu klasyczna muzyka klawesynowa w aranżacji i wykonaniu Krzysztofa Komedy, w drugiej zaś - partie mulitinstrumentalne (sola na różnych instrumentach, przede wszystkim na perkusji) przypominające ówczesne dokonania awangardowego Studia Eksperymentalnego Polskiego Radia, wreszcie głos kobiecy, bezsłowny szept niczym zaklęcie, a następnie głos męski wyrażający przerażenie tym, co się stało.

Polański po raz kolejny zaskoczył swoich widzów. Nie tylko on zresztą. Warto w tym miejscu dodać, iż Lampa z jej ewidentnym nowatorstwem w dziedzinie sonorystyki filmowej stanowi też ciekawy przyczynek do twórczości kompozytorskiej Komedy. To jego pierwsze filmowe rozstanie z jazzem. Efekt, jaki osiągnął, wyznacza w istocie nowy szlak poszukiwań w dziedzinie muzyki filmowej, wyprzedzają- 
cy o kilka lat to, co stanie się jego znakomitym artystycznym osiągnięciem w dwóch duńskich pełnometrażowych filmach Henninga Carlsena Co z nami? (1963) i Głód (1965).

Gdy spadaja anioły - swobodna adaptacja opowiadania Leszka Szymańskiego, które ukazało się drukiem na łamach tygodnika „Kierunki” w roku 1956 - to zrealizowany na pożegnanie ze Szkołą w 1959 roku film dyplomowy Romana Polańskiego. Po sukcesie Dwóch ludzi $z$ szafą reżyser tym razem postanowił nakręcić większą od poprzedniej, bardziej rozbudowaną pod względem fabularnym i narracyjnym, formę filmową. Nadal miał to być film krótkometrażowy, tyle że w tym przypadku chodziło o produkcję pomyślaną i zainscenizowaną $\mathrm{z}$ większym rozmachem, $\mathrm{z}$ galerią postaci i statystami w kostiumach historycznych, z efektami pirotechnicznymi i własną wyszukaną scenografią, co w ówczesnych etiudach studenckich kręconych w Łodzi ze względu na ich skromny budżet - było rzadkością i niewątpliwym ewenementem.

Majstersztykiem realizacyjnym dyplomowej etiudy Romana Polańskiego jest kapitalna scenografia. Zaprojektowali ją wspólnie dwa młodzi mistrzowie: ówczesny student Akademii Sztuk Pięknych w Krakowie Kazimierz Wiśniak i Roman Polański. Jej wyszukane elementy składowe wprawiają w zdumienie bogactwem wyobraźni. Mamy tu partie barwne i czarno-białe, jest też fenomenalnie zaprojektowana, przywodząca na myśl renesansowe malarstwo pejzażowe, kilkuplanowa perspektywa ogólnego ujęcia bitwy na wzgórzu czy obwieszone zmrożonymi czerwonymi jabłkami drzewo w śniegu.

Pomysłowość scenograficzna obu twórców co chwila zaskakuje w trakcie oglądania, osiągając w tym niskobudżetowym filmie niezwykle wyśrubowany poziom. Wiśniak i Polański potrafili doprawdy wykreować coś z niczego. Mamy tutaj z jednej strony umowną miniaturową makietę miasta $\mathrm{z}$ wysuniętym $\mathrm{w}$ naszą stronę centralnym elementem, jakim jest anioł na wieży ratuszowej uderzający $\mathrm{w}$ dzwon. Z drugiej zaś - zdumiewająco precyzyjnie wykonaną werystyczną dekorację $\mathrm{w}$ postaci podziemnego szaletu, w którym rozgrywa się znaczna część opowieści.

Obiekt ten był częściowo wzorowany na jego zabytkowym XIX-wiecznym odpowiedniku, secesyjnym szalecie pod Sukiennicami w Krakowie. Na ekranie przedstawia się wprost imponująco. Gipsowe odlewy fajansowych pisuarów wykonali osobiście obaj projektanci. Co więcej, zbudowany w szkolnym atelier podziemny szalet ma sufit z matowych szklanych kafli, po którym górą na powierzchni chodzą ludzie. Sufit ten nie jest jakąś banalną, statyczną w swym wyrazie dekoracją. Polański wyznaczył mu ważną rolę dramaturgiczną w finałowej scenie Gdy spadaja anioły.

Niezmiernie rzadko się zdarza, by scenografii etiudy filmowej przypadały tak istotne zadania. Całość konstrukcji scenograficznej i jej niebywale starannie wypracowana architektura mają tutaj charak- 
ter absolutnie profesjonalny, budząc zdumienie i podziw widza. Mowa przecież o szkolnym filmie.

Nasuwa się w tym miejscu pytanie, jak możliwe było coś takiego w przypadku produkcji studenckiej etiudy dyplomowej, z natury rzeczy operującej niskim budżetem i od strony realizacyjnej nie pretendującej przecież do niczego więcej niż produkt offowy?

Ten warsztatowy aspekt łódzkiej Szkoły Filmowej jej ówczesny student Krzysztof Malkiewicz skomentuje po latach następująco: „Była jakby małą wytwórnią filmową, co stało się jej wielkim walorem. Do obsługi kilkudziesięciu studentów zatrudniano kilkudziesięciu fachowców." [8] Zaś Andrzej Kostenko dodaje:

Polańskiemu do filmu dyplomowego „Gdy spadają anioły” szkolni stolarze wykonali taki szalet, że profesjonaliści z wytwórni filmów fabularnych by się tego nie powstydzili. Czego tam nie było - sztukaterie, gipsowe odlewy, pisuar, który naprawdę działał. Wszystko to powstało w szkolnym atelier na Marysinie. Myśmy sobie z tego nie zdawali sprawy, ale to była Szkoła dla milionerów.[9]

Sam Roman Polański, komentując na kartach wspomnieniowej książki Roman swój dawny wyczyn sprzed lat, przedstawił taką oto autorską eksplikację:

Tematem miało być nudne na pozór życie jednej z tych osób, które mijamy, nie zwracając na nie żadnej uwagi. [...] Babcia klozetowa $z$ szaletu miała mistyczne widzenie. Los takiej osoby wydawał mi się kwintesencją szarzyzny i monotonii codziennego życia. Nikomu nigdy nie przyszłoby na myśl przyglądać się siedzącej nad żałosnym spodkiem z monetami staruszce o twarzy bez wyrazu, ze wzrokiem wbitym w pustkę. Któż mógłby przypuszczać, że życie tej kobiety było pełne namiętności i dramatów. Taka była geneza filmu „Gdy spadają anioły”. Miał dać widzom wrażenie rozmachu, mimo że nie powinien przekraczać dwudziestu minut. Nade wszystko zaś chciałem nadać mu romantyczny, niemal barokowy styl na krawędzi kiczu, tak aby publiczność odebrała tę historię jako sen na jawie kobiety u schyłku życia. Starzy ludzie fascynowali mnie. Zawsze miałem poczucie, że starzy - nawet bardziej niż dzieci - zasługują na opiekę i uwagę. Mimo wieloletnich doświadczeń są tak bezradni, a wobec nadchodzącej śmierci zrezygnowani i bezsilni.

[...] „Gdy spadają anioły” jest galerią portretów moich przyjaciół. Warunki fizyczne wciąż liczyły się dla mnie bardziej niż umiejętności aktorskie, wolałem więc raczej wykonawców niezawodowych niż zmanierowanych aktorów, wychowanych w tradycji polskich szkół teatralnych. Andrzej Kondratiuk grał rolę żołnierza, syna starej kobiety, Andrzej Kostenko - szukającego przygody homoseksualistę, Kuba Goldberg - inkasenta, który przychodzi odczytać stan licznika, a Barbara - babcię w młodości.

W roli głównej obsadziłem pensjonariuszkę domu dla starców. Miała ponad osiemdziesiąt lat, a na jej twarzy wyrażającej łagodność i absolutną

[8] Cytowana wypowiedź Krzysztofa Malkiewicza

[9] Ibidem, s. 234.

pochodzi z książki: Filmówka. Powieść o tódzkiej

Szkole Filmowej, op.cit., s. 234. 
pustkę, obok rezygnacji, apatii, widniały ślady dawnej urody. Kobieta zaakceptowała moją propozycję, nie bardzo rozumiejąc, na czym ma polegać jej zadanie. Nie miała żadnych wymagań, była bierna, nie bardzo świadoma tego, co się dzieje. Zbudowała postać na podstawie moich czysto technicznych wskazówek.[10]

W zasadzie nic dodać, nic ująć. Warto może jeszcze zająć się kilkoma pominiętymi przez Polańskiego szczegółami poetyki samego filmu.

Należy do nich w pierwszej kolejności luźno z sobą spleciona, epizodyczna konstrukcja całości. Ukazując okrucieństwo świata i ogrom cierpień, na jakie naraża on nieustannie żyjących, autor zbudował wielowątkową akcję, w której swobodnie przenosi nas z epoki do epoki (czasy wojen napoleońskich, wojna rosyjsko-japońska, I wojna światowa) i z miejsca na miejsce (pola bitew, tereny frontowe, Kraków współczesny i in.). Dyplomowa etiuda Polańskiego, zgodnie z jego zamysłem, osiągnęła wymiar jednocześnie kameralny i epicki. Sposób,

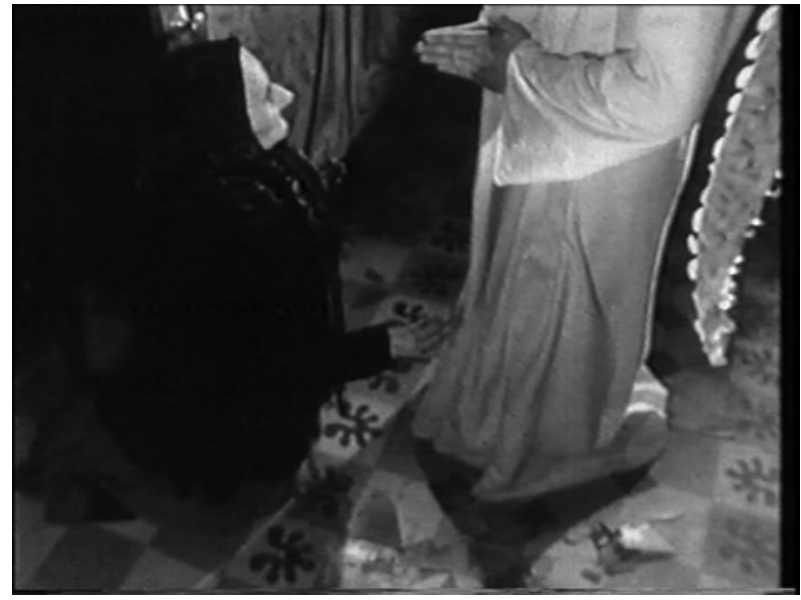
w jaki pokazał jednostkę w historii, wybiega daleko w przyszłość, każąc przywołać nowoczesne koncepcje spod znaku tak zwanej mikrohistorii, w której zwierciadle przegląda się człowiek w jego zmaganiach z nieludzką i przemożną siłą wielkiej historii.

Na koniec uwaga filmograficzna. Otóż w filmografii Gdy spadaja anioły Roman Polański figuruje jako odtwórca roli Starej kobiety. Istotnie, oglądamy go w paru scenach na ulicach Krakowa - między innymi w tej, gdy usiłuje wręczyć pakunek odchodzącemu na front synowi. Należy jednak także odnotować jeszcze inny udział aktorski Polańskiego w tym filmie. W epizodzie frontowym (z Andrzejem Kondratiukiem) widzimy go w roli żołnierza, któremu szrapnel urywa obie nogi. Przeraźliwy śmiech nieszczęśnika w chwilę po odniesieniu tej potwornej kontuzji w wykonaniu samego Romana Polańskiego, podczas gdy kamera z całym okrucieństwem odsłania naszym oczom to, co się stało w chwili wybuchu szrapnela, trudno doprawdy zapomnieć.

Gruby i chudy (oryginalny tytuł francuski Le gros et le maigre) nie jest, formalnie rzecz biorąc, etiudą studencką. Nie zmienia to jednak w niczym faktu, że zarówno w sposobie realizacji, jak i w kształcie, jaki został mu nadany, film ten stanowi kapitalny przykład eksportu na Zachód wypracowanej w Łodzi nowatorskiej formuły szkolnej etiudy fabularnej. Formuły, która dzięki Polańskiemu i jego kolegom zdążyła już wcześniej zwrócić na siebie uwagę dzięki licznym 
sukcesom Dwóch ludzi z szafą w międzynarodowych konkursach i na prestiżowych festiwalach filmowych w Brukseli, San Francisco, Vancouver, Amsterdamie i Montevideo.

W Grubym i chudym poza francuską kozą, której przypadła bardzo eksponowana rola, wystąpili: przyjaciel reżysera, niedźwiedziowaty Andrzej Katelbach (po służbie w RAF osiedlony we Francji, wówczas właściciel wytwórni sztucznych kwiatów) oraz Roman Polański. Ten ostatni daje tu popis gry aktorskiej, dokładając do tego partie taneczno-baletowe i - uwaga! - solówkę na instrumentach perkusyjnych godną Gene’a Krupy. Już tylko ta jedna scena zasługuje na to, by tę etiudę koniecznie obejrzeć. Niewiele zresztą brakowało, a Gruby $i$ chudy w ogóle by nie powstał.

Możliwość nakręcenia pierwszego swojego filmu za granicą wychodził mało komu wtedy znany twórca $\mathrm{z}$ Polski podczas kilkutygodniowego pobytu w Paryżu, jesienią 1960 roku. Jak zwykle w takich sytuacjach, aby w ogóle doszło do realizacji planowanej krótkometrażówki, musiały zostać zawarte określone kompromisy nie tyle twórcze, co produkcyjne. Chcąc nie chcąc, Polański przystał na nie bez chwili wahania. Wydawało się, iż reszta, czyli sama realizacja filmu na planie w podparyskim Meudon, pójdzie jak po maśle.

Gruby $i$ chudy jako krótkometraźówka stanowią kolejny w twórczości Polańskiego przykład minimal artu. Prosta linearna konstrukcja oparta na serii gagowych epizodów. Wszystko bez jednego słowa, w konwencji niemej burleski. Zdjęcia dzienne ze światłem słonecznym. Jedna sceneria $\mathrm{z}$ wnętrzem i plenerem, minimalna liczba rekwizytów (fotel, stolik, kajdanki z łańcuchem, fuzja, łuk sportowy i tarcza łucznicza, wachlarz, skrzypce, perkusja, garnki, patelnie i sprzęty kuchenne). Pomysłowy Polański wykorzystał nawet jako dekorację na podparyskiej łące sztuczne kwiaty z wytwórni Katelbacha. Wszystko wydawało się być dosłownie w zasięgu ręki. A jednak nawet tak skromnie pomyślana produkcja z minimalnym budżetem całkiem nieoczekiwanie przysporzyła jej twórcom nie lada kłopotów.

W trakcie realizacji okazało się, że kanadyjski producent Grubego i chudego Jacques Brunet nagle opuścił Paryż, zostawiając za sobą czeki bez pokrycia. Postawiło to całe przedsięwzięcie pod wielkim znakiem zapytania. Szczęśliwym trafem znalazł się jednak ktoś, kto gotów był urzeczywistnić całe przedsięwzięcie bez względu na poniesione koszta. Pierwszy zagraniczny film Polańskiego powstał tylko dzięki temu, że produkcję sfinansował $\mathrm{z}$ własnej kieszeni i doprowadził do końca właściciel niewielkiego paryskiego studia filmowego Claude Joudioux.

Jego osobista determinacja i pomocna dłoń sprawiły, że udało się rzecz nie tylko nakręcić, ale i zmontować oraz udźwiękowić. Niewiele zresztą ryzykowal. W owym czasie francuskie Ministerstwo Kultury - nawiązując poniekąd do świetnych tradycji awangardowego kina francuskiego lat dwudziestych - zarządziło, aby każdy seans w kinach na terenie Francji obowiązkowo zaczynał się od nadprogra- 
mu w postaci krótkiego metrażu. Była to decyzja światła i dalekosiężna w skutkach. Jej podjęcie i konsekwentne wprowadzenie w obieg codziennego życia filmowego ożywiło natychmiast produkcję różnego rodzaju etiud.

Efekty nie dały na siebie długo czekać, by tylko przywołać w tym miejscu klasyczne dzisiaj krótkie filmy zrealizowane między innymi przez: Alaina Resnais, Louisa Malle'a, Jacquesa Tatiego, Alberta Lammorisse’a, Chrisa Markera czy Pierre’a Étaixa. Kręcenie filmów krótkometrażowych stało się z dnia na dzień opłacalne dla producentów, zaś artystycznie najlepsze z tych utworów otrzymywały od państwa gratifikacje finansowe. Tak więc Gruby i chudy zawdzięcza swoje powstanie pomyślnej koniunkturze dla tego typu twórczości, a sama opowiastka - z jej prostą konstrukcją, przewrotną wymową i specyficznym poczuciem humoru - bardzo przypadła do gustu wybrednej widowni klubów filmowych w Paryżu i innych miastach.

Szczęśliwym zbiegiem okoliczności, po występach na VIII Międzynarodowym Festiwalu Kultury Studenckiej w Grenoble we wrześniu 1960 na krótko przyjechał do Paryża Krzysztof Komeda. Przyjaciel Polańskiego wkrótce zajął się skomponowaniem i nagraniem muzyki do Chudego i grubego. Do legendy tego filmu przeszedł przemyślny sposób, w jaki dostarczone zostało pianino niezbędne do pracy kompozytorowi. Trafiło ono do mieszkania, w którym rezydowali młodzi polscy filmowcy, przez balkon na trzecim piętrze śródmiejskiej kamienicy przy rue Vaugirard.

Rezultat muzyczny, jaki osiągnął w tym filmie Komeda, daleko wykracza poza obiegowe standardy muzyki filmowej. Nie chodzi tu wcale o piękny motyw przewodni, lecz o efekt ostrego dysonansu dźwiękowego, jaki wywołuje potworne rzępolenie Chudego na skrzypcach. Trzeba doprawdy niezwykłej odwagi i jednocześnie niezachwianego poczucia własnej wartości, aby tak strasznie fałszować i tak źle grać, będąc znakomitym muzykiem. Jedynie wspomniany leitmotiv przekonuje ostatecznie widza, że kompozytor i wykonawca muzyki do Grubego i chudego, mimo wiolinowej katastrofy, która torturuje nasze uszy, był jak zwykle w dobrej formie.

Czegoś podobnego nie było dotąd w całej powojennej polskiej Ssaki kinematografii. Awangardowy film za prywatne pieniądze nakręcony w PRL w warunkach produkcji niezależnej. Niezależnej z konieczności, bo scenariusz Ssaków odrzuciło wcześniej kierownictwo wytwórni „Se-Ma-For”.

Pomysł zrodził się podczas wspólnego pobytu latem 1960 roku na Zachodzie. Na miejscu, czyli po powrocie do Łodzi, ekipę filmu stworzyła grupa kilku przyjaciół. Pieniądze na realizację wyłożyli: Wojciech Frykowski, który został producentem, i Andrzej Kostenko (asystent reżysera). Współscenarzystą i operatorem był Andrzej Kondratiuk. W głównych rolach wystąpili: Henryk Kluba i Michał Żołnierkiewicz. Kamerę Arriflex wypożyczył studentom profesor łódz- 
kiej Szkoły Filmowej Stanisław Wohl. Frykowski z właściwą sobie przedsiębiorczością kupił „na lewo” kilkaset metrów negatywu 35milimetrowej taśmy z laboratoryjnych zapasów. Tak zaopatrzona ekipa wyjechała zimą 1961 roku do Zakopanego, gdzie wkrótce ruszyły zdjęcia kręcone w śnieżnym krajobrazie Kościeliska.

Wyjściowy pomysł całej opowieści Ssaki zawdzięczają Andrzejowi Kondratiukowi, który dzięki pracy w muzeum jeszcze przed studiami zafascynował się rodzimym malarstwem, w tym między innymi obrazami znakomitego młodopolskiego malarza Witolda Wojtkiewicza. Inspiracji dostarczyło scenarzyście jedno z płócien Wojtkiewicza zatytułowane Przechadzka w zaprzegu (1906).

Film Ssaki powstał dzięki temu, że obejrzałem obrazek Witolda Wojtkiewicza Przechadzka w zaprzegu, gdzie jeden cymbał ciągnie drugiego cymbała na wózku. Zamieniłem wózek na sanki. Przesłanie filmu było krótkie - każdy chce być tym na sankach, a nie tym, który ciągnie. Panował okres filozoficznych przypowiastek i Saski powstały właśnie na tej fali. Początkowy pomysł rozwinąłem z Polańskim podczas naszego pobytu we Francji.[11]

Polański wniósł do malarskiej wizji Wojtkiewicza własną inwencję i tchnął w nią całkiem nowego współczesnego ducha. Realizacja filmu nie należała do łatwych, a aktorzy, Kluba i Żołnierkiewicz dostali na planie ciężką szkołę. Oddajmy w tym miejscu głos samemu reżyserowi:

Kręciliśmy w śniegu: cała akcja rozgrywa się na czystym, idealnie białym tle. Film składa się z ciągu wizualnych gagów. Gdzieś daleko, w pustej przestrzeni ukazuje się ciemny punkcik. Stopniowo przybiera kształty dwóch ludzi i sanek. Jeden siedzi na sankach, drugi go ciągnie. Rozpoczynają nieustającą walkę o władzę. Każdy chce za wszelką cenę być ciągnięty. Wszystkie chwyty są dozwolone: od litości i uczuciowego szantażu do przemocy fizycznej.

Podobnie jak w filmach rysunkowych, ni stąd ni zowąd, zjawiają się rekwizyty. Może najbardziej efektowny gag następuje, kiedy jeden $\mathrm{z}$ facetów udaje, że jest ranny i zaczyna owijać się bandażem. Bandaż zlewa się ze śnieżnym krajobrazem tak, że człowiek staje się całkowicie niewidoczny. W końcu sanki kradnie sprzedawca kiełbasek - epizod grany przez Frykowskiego. Po czym adwersarze wędrują dalej pieszo usiłując wdrapać się jeden drugiemu na plecy.[12]

Wspomnieniowa relacja twórcy nie oddaje w żadnym stopniu aktorskiego wysiłku odtwórców głównych ról. Obaj wykazali się niezwykłym poświęceniem, dając z siebie wszystko. Było z pewnością warto, bowiem efekt ekranowy przerósł najśmielsze oczekiwania. Po raz kolejny realizm Polańskiego pokazał siłę swego wyrazu dzięki wielkiemu zaangażowaniu aktorów, których praca i poświęcenie na planie zdjęciowym budzi najwyższy szacunek.

[11] Cytowana wypowiedź Andrzeja Kondratiuka pochodzi z tomu: Filmówka. Powieść o łódzkiej Szkole Filmowej, op.cit., s. 137.
[12] R. Polański, op.cit., s. 137. 
Muzykę do etiudy fabularnej Polańskiego skomponował, za)aranżował i nagrał Krzysztof Komeda. I tym razem również na ścieżce dźwiękowej filmu znalazło się coś zaskakująco śmiałego i niebywale oryginalnego. Temat przewodni muzyki do Ssaków natychmiast wpada w ucho; nic dziwnego, cechuje go bowiem uroda melodyczna równa bodaj tej z Dwóch ludzi z szafa. Kompozytor zdecydował się jednak w tym przypadku na karkołomny zabieg połączenia z sobą dwóch całkiem różnych żywiołów wykonawczych. Jeden $\mathrm{z}$ nich stanowili muzycy jazzowi, drugi - grupa muzyków amatorów złożona z łódzkich mandolinistów. Ów muzyczny konflikt dwu całkiem odmiennych stylów uprawiania muzyki pozwolił Komedzie jako kompozytorowi i aranżerowi w jednej osobie wytworzyć na ścieżce dźwiękowej zamierzo-

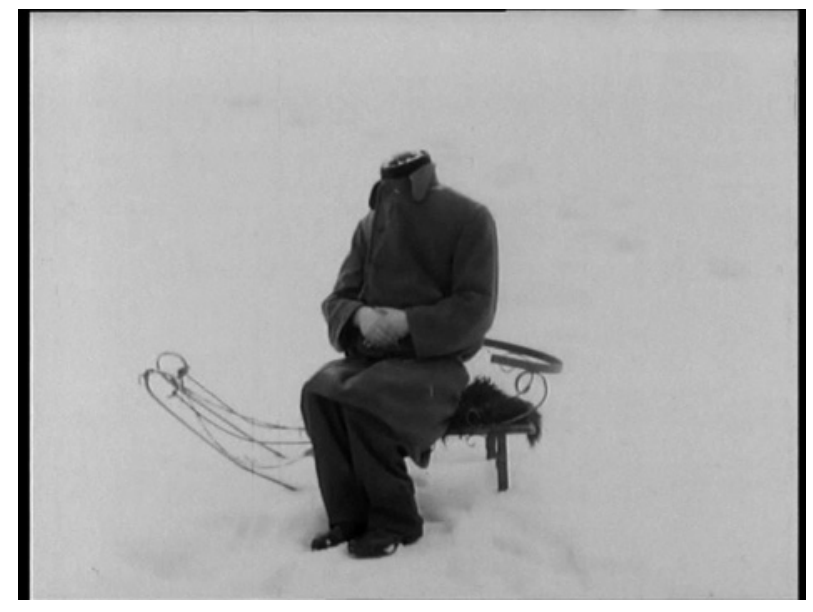
ny dysonans. Rezultat okazał się fantastycznie nośny. Na ekranie nie Ssaki pada ani jedno słowo. Całość dyskursu przyjmują na siebie obraz i muzyka.

Zdumiewa pomysłowość inscenizacji, ogrywająca wyjściowy pomysł zaczerpnięty z obrazu Wojtkiewicza do granic możliwości czy raczej niemożliwości. Analityczny rozbiór filmu na stole montażowym pozwala lepiej dostrzec i odkryć niezwykłe bogactwo zastosowanych figur montażowych. Puszczona w ruch na początku etiudy (por. wcześniejsze uwagi o początkowych scenach Dwóch ludzi z szafa), zasada paralelizmu (sytuacji ekranowych, ujęć, scen, epizodów, fraz montażowych) daje o sobie znać na różnych poziomach kompozycji całości. Ekwiwalencje budowane przez Polańskiego czynią cały utwór niezwykle zwartym. Dzięki konsekwentnemu utrzymaniu przyjętej i respektowanej przez twórcę zasady ekwiwalencji, dzieło to osiąga zaskakująco wysoki poziom artystyczny, który każe umieścić pośród największych dokonań polskiej sztuki krótkiego metrażu lat sześćdziesiątych.

Ssaki oglądane pół wieku później imponują niezwykłą lekkością i precyzją ich konstrukcji. Z jednej strony, wydaje się ona najprostszą z możliwych, z drugiej strony, okazuje się niezwykle finezyjna w sferze niesionych przez siebie znaczeń. Jej reżyserowi udało się uzyskać doskonale wyważoną równowagę między powagą powiastki filozoficznej a absurdalnym żartem filmowym. Jak przystało na absolwenta łódzkiej Szkoły Filmowej, Polański zaprezentował warsztat reżyserski na bardzo wysokim poziomie. Wykorzystał przy tym wypracowaną przez siebie przy okazji Dwóch ludzi z szafą konwencję filmowej etiudy w sposób najpełniejszy z możliwych, to znaczy angażując w maksymalnym stopniu grę wyobraźni, poetycką wizję świata i element improwizacji umożliwiający jej wykreowanie. 
Dotyczy to w tym samym stopniu zaczerpniętego z burleski slapstickowej stylu gry aktorskiej, w której znalazło się miejsce na błazenadę i happening (w tej dziedzinie młody Polański jest niewątpliwym prekursorem happeningowej inscenizacji w kinie współczesnym), co sposobu opowiadania obywającego się bez jakichkolwiek schematycznych fabularnych uzasadnień i - śladem Dwóch ludzi z szafa - swobodnie przechodzącego od jednego epizodu do drugiego. Pointa, jaka po nich następuje, należy do majstersztyków sztuki krótkiego metrażu, zaskakując widza i przenosząc całą opowieść w inny wymiar.

Na Ssakach, będących szczytowym osiągnięciem poetyki wypracowanej przez tego filmowca we wczesnym okresie jego twórczości, kończy się znakomita seria wczesnych etiud Romana Polańskiego z lat 1955-1961. Poprzedzają one realizację jego pełnometrażowego debiutu kinowego, jakim stał się nakręcony latem i wczesną jesienią 1961 Nóż $w$ wodzie (premiera 9 marca 1962).

Podsumowanie

Spojrzenie na wczesną twórczość reżysera filmowego niekoniecznie musi się wiązać $\mathrm{z}$ taryfą ulgową. A już z pewnością taryfy takiej nie wymagają dla siebie pierwsze próby reżyserskie bohatera niniejszego studium. Omówione powyżej etiudy szkolne Romana Polańskiego mają charakter modelowy w tym sensie, że zapisała się w nich nie tylko indywidualna wyobraźnia ich twórcy, lecz także szersza świadomość tego, co w gruncie rzeczy jest, bywa i może być, studencką etiudą filmową. Podobnie jak Majewski, Osiecka, Kondratiuk, Skolimowski, Zanussi, Kostenko, Papuziński, Solarz, Szczechura, Holender, Samosiuk czy Leszczyński - należał Polański do grona tych studentów reżyserii w łódzkiej Szkole Filmowej po Październiku 1956, którzy, dostając do dyspozycji kamerę i taśmę, potrafili w największym stopniu skorzystać z danej im szansy.

Na przekór temu, co nieraz pisano, autor Rozbijemy zabawę, Dwóch ludzi z szafą i Gdy spadają anioły w gruncie rzeczy stronił od reżyserskiego ekscesu i epatowania widza. Nie o to naprawdę chodziło. Każda z jego wczesnych prac - od Morderstwa do Ssaków - była próbą zmierzenia się $\mathrm{z}$ indywidualnie przezeń rozpoznawaną i przyswajaną tradycją zarówno warsztatową, jak i artystyczną. Najdawniejsze utwory Polańskiego odkrywają zadziwiająco dojrzałą świadomość młodego artysty.

Jeśli wracamy dzisiaj do znakomitej tradycji etiud filmowych, jakie powstawały w latach pięćdziesiątych w łódzkiej Szkole Filmowej, nie sposób nie zauważyć, że od niego wszystko się zaczęło. To on sprawił, że etiuda filmowa stała się czymś więcej niż warsztatowym ćwiczeniem, nadał jej walor artystycznej autonomii i wyprowadził z akademii w szeroki świat, sprawiając, że weszła w pełni zasłużenie w krąg sztuki. Spośród dziewięciu, jakie nakręcił, kilka zyskało znaczny rozgłos i prestiżowe nagrody. Sukces ten zawdzięczały w znacznej mierze temu, iż jedna po drugiej stanowiły dla niego pole walki o własną sztukę i osobisty wyraz artystyczny. Czas pokazał, że była to batalia wygrana. 
Dzięki szkolnym filmom Polańskiego i grupy jego utalentowanych kolegów całkowicie zmieniła się panująca dotąd formuła etiudy operatorskiej i reżyserskiej. Do głosu doszła twórczość filmowa w pełnym tego słowa znaczeniu. A wraz z nią: indywidualna wyobraźnia, niepowtarzalny wyraz, odkrywczość i oryginalność. W ogromnej mierze przemiana ta jest zasługą samego Polańskiego. Morderstwo, Rozbijemy zabawe, Dwaj ludzie z szafa, Gdy spadaja anioły - zdumiewają po latach niebywałą inwencją, dyscypliną i oryginalnością wypracowanej w nich formy.

Wszystkie te filmy wystawiają po latach jak najlepsze świadectwo nie tylko ich autorowi, lecz również Uczelni, która potrafiła zapewnić swoim słuchaczom $\mathrm{w}$ tamtych czasach tak wielką wolność twórczego wypowiadania się w języku ruchomych obrazów i tak wysoki stopień wewnętrznej autonomii własnych eksperymentów artystycznych. Formuła, jaką zaproponował młody Polański, rychło wyszła poza ramy szkolnego ćwiczenia i poza mury łódzkiej PWSF. Dlatego do powyższych rozważań na pełnoprawnych zasadach włączone zostały również dwa filmy krótkometrażowe młodego twórcy zrealizowane w latach 1960-1961 poza Szkołą Filmową: Gruby i chudy (Le gros e le maigre) oraz Ssaki.

Wczesne prace filmowe Polańskiego nie są tylko serią warsztatowych wprawek początkującego reżysera i aktora. W każdej z nich na swój sposób daje o sobie znać zaskakująca zapowiedź czegoś, co wydarzyło się później i co stanowi efekt jego dalszych poszukiwań twórczych. W tym sensie etiudy, jakie nakręcił w Szkole i poza nią, nie są tylko ćwiczeniami ręki i oka, lecz należą najzupełniej integralnie i pełnoprawnie do jego artystycznego dorobku. Nie ma tutaj potrzeby stosowania żadnej taryfy ulgowej dla studenta, ani też kogoś, kto dopiero aspiruje do zawodu, zdobywając $\mathrm{z}$ filmu na film profesjonalne szlify.

Etiudy Romana Polańskiego - zarówno nakręcone w łódzkiej Szkole Filmowej, jak i zrealizowane poza nią - stanowią dzisiaj kanon tego gatunku. Spostrzeżenie to zdaje się nie budzić dzisiaj żadnych oporów ani wątpliwości. Tymczasem, głębsza i bardziej wnikliwa analiza fenomenu, jaki stanowią, prowadzi do całkiem odmiennego wniosku. Kanoniczny, by tak rzec, charakter tych filmów (zwłaszcza Rozbijemy zabawę, Dwóch ludzi z szafa i Gdy spadaja anioły) ma swoje źródło w ich niezwykłej śmiałości, oryginalności i osobności. Ich unikatową oryginalność i wyjątkowość widać zwłaszcza na tle tego, co za etiudę studencką wcześniej - to jest przed rokiem 1957 - uchodziło w samej Szkole Filmowej, a także daleko poza jej murami.

\section{Rower}

Filmografia

Etiuda fabularna

Scenariusz i reżyseria: Roman Polański

Zdjęcia: Nikoła Todorow

Wykonawcy: Roman Polański (Chłopiec) i Adam Fiut (Napastnik)

Produkcja: Państwowa Wyższa Szkoła Filmowa w Łodzi, 1955 
Film barwny na taśmie $35 \mathrm{~mm}$

Zdjęcia kręcono w Krakowie.

Etiuda nie zachowała się.

\section{Morderstwo}

Etiuda fabularna

Scenariusz i reżyseria: Roman Polański

Zdjęcia: Nikoła Todorow

Produkcja: Państwowa Wyższa Szkoła Filmowa w Łodzi, 1957

Film czarno-biały na taśmie $35 \mathrm{~mm}$, Agfa, niemy

Długość filmu: $45 \mathrm{~m}$

Czas projekcji: 1 minuta 30 sekund

Uśmiech zębiczny

Etiuda fabularna

Scenariusz i reżyseria: Roman Polański

Zdjęcia: Henryk Kucharski

Wykonawca: Kola Todorow (Podglądacz)

Produkcja: Państwowa Wyższa Szkoła Filmowa w Łodzi, 1957

Film czarno-biały na taśmie $35 \mathrm{~mm}$, Agfa, niemy

Długość filmu: $37 \mathrm{~m}$

Czas projekcji: 1 minuta 30 sekund

\section{Rozbijemy zabawe}

Etiuda dokumentalna

Scenariusz i reżyseria: Roman Polański

Asystent reżysera: Andrzej Kostenko

Zdjęcia: Marek Nowicki, Andrzej Galiński

Wykonawcy: Jan Rutkiewicz (organizator imprezy), Janusz Majewski (uczestnik zabawy), Jan Cesarski, Andrzej Łowicz, Wojciech Tomaszewski, Wiesław Turowski, Andrzej Ziółkowski (chuligani), studenci PWSF i in.

Kierownictwo produkcji: Maciej Żuralski

Produkcja: Państwowa Wyższa Szkoła Filmowa w Łodzi, 1957

Film czarno-biały na taśmie $35 \mathrm{~mm}$, Agfa

Długość filmu: $226 \mathrm{~m}$

Czas projekcji: 8 minut 49 sekund

Zdjęcia kręcono na terenie PWSF w Łodzi.

\section{Dwaj ludzie zszafa}

Etiuda szkolna zrealizowana na Wydziale Operatorskim PWSF

Scenariusz i reżyseria: Roman Polański

Asystent reżysera: Andrzej Kostenko

Zdjęcia: Maciej Kijowski

Asystent operatora: Jakub Dreyer

Muzyka: Krzysztof Komeda

Muzyka w wykonaniu Sekstetu Komedy

Wykonawcy: Henryk Kluba (Nosiciel szafy), Jakub Goldberg (Nosiciel szafy), Roman Polański, Stanisław Michalski, Adam Fiut (Chuligani) i inni 
Kierownictwo produkcji: Ryszard Barski

Produkcja: Państwowa Wyższa Szkoła Teatralna i Filmowa w Łodzi, 1958

Film czarno-biały na taśmie $35 \mathrm{~mm}$, Agfa

Długość filmu: $425 \mathrm{~m}$

Czas projekcji: 15 minut

Zdjęcia kręcono w Gdańsku, Sopocie i Jastarni.

Nagrody i wyróżnienia: Brązowy Medal (trzecia nagroda ex aequo) na Międzynarodowym Konkursie Filmów Eksperymentalnych podczas Festiwalu na Wystawie Światowej Expo'58 w Brukseli; Złote Wrota dla najlepszego filmu eksperymentalnego na II MFF w San Francisco, 1958; Nagroda tygodnika „Film” za reżyserię dla Romana Polańskiego na Festiwalu Filmów PWSTiF w Warszawie, 1958; Dyplom Honorowy V MFFK w Oberhausen dla Romana Polańskiego, 1959; Nagroda w kategorii filmów eksperymentalnych na MFF w Vancouver, 1960; Nagroda Międzynarodowego Festiwalu Filmów Studenckich w Amsterdamie, 1960; I Nagroda na MFF Eksperymentalnych w Montevideo, 1960

\section{Lampa}

Etiuda fabularna

Scenariusz i reżyseria: Roman Polański

Asystenci reżysera: Andrzej Kostenko, Wasyl Mirczew

Zdjęcia: Krzysztof Romanowski

Współpraca operatorska: Adam Holender

Muzyka: Krzysztof Komeda (uwaga: udział muzyczny Komedy w tym filmie miał charakter przede wszystkim wykonawczy i nie został uwzględniony w napisach)

Produkcja: Państwowa Wyższa Szkoła Teatralna i Filmowa w Łodzi, 1959

Film czarno-biały na taśmie $35 \mathrm{~mm}$, Agfa

Długość filmu: $212 \mathrm{~m}$

Czas projekcji: 6 minut 55 sekund

\section{Gdy spadaja anioly}

(tytuł roboczy „Babcia”)

Film dyplomowy

Scenariusz na motywach opowiadania Leszka Szymańskiego pt. „Klozet babcia" i reżyseria: Roman Polański

Asystent reżysera: Andrzej Kostenko

Zdjęcia: Henryk Kucharski

Scenografia: Kazimierz Wiśniak, Roman Polański

Wykonawcy: Barbara Kwiatkowska (Babcia w młodości), Andrzej Kondratiuk (Ułan, Syn staruszki ginący na wojnie, Anioł), Henryk Kluba (Dezerter), Henryk Kucharski (pijany młodzieniec w szalecie), Jakub Goldberg (Inkasent), Andrzej Kostenko (Homoseksualista), Ryszard Filipski (Homoseksualista), Roman Polański (Stara kobieta podająca pakunek synowi wyruszającemu na front oraz Żołnierz bez nóg), Stefan Bartik (Ojciec dziewczyny) i inni 
Produkcja: Państwowa Wyższa Szkoła Teatralna i Filmowa w Łodzi, 1959 Film czarno-biały i barwny na taśmie $35 \mathrm{~mm}$

Długość filmu: $645 \mathrm{~m}$

Czas projekcji: 20 minut 47 sekund

Zdjęcia kręcono w Krakowie, w okolicach Łodzi i w atelier Wytwórni Filmów Fabularnych w Łodzi.

\section{Le gros et le maigre}

(tytuł pierwotny: Łańcuch, tytuł polski: Gruby i chudy)

Scenariusz i reżyseria: Roman Polański

Współreżyseria i montaż: Jean-Pierre Rousseau

Zdjęcia: Jean-Michel Roussaguet

Wykonawcy: Roman Polański (Chudy) i Andrzej Katelbach (Gruby)

Muzyka: Krzysztof Komeda

Kierownictwo produkcji: Claude Joudioux

Produkcja: Studio A.P.E.C., Francja, 1961

Film czarno-biały na taśmie $35 \mathrm{~mm}$

Długość filmu: $405 \mathrm{~m}$

Czas projekcji: 14 minut 22 sekundy

Zdjęcia kręcono wczesną jesienią 1960 roku w Meudon pod Paryżem. Wyróżnienie na Międzynarodowym Festiwalu Filmów Krótkometrażowych w Tours, 1961

\section{Ssaki}

Scenariusz: Roman Polański, Andrzej Kondratiuk

Reżyseria: Roman Polański

Asystent reżysera: Andrzej Kostenko

Zdjęcia: Andrzej Kondratiuk

Scenografia: Jerzy Skarżyński

Muzyka: Krzysztof Komeda

Montaż: Halina Prugar, Janina Niedźwiedzka

Wykonawcy: Henryk Kluba (Wędrowiec), Michał Żołnierkiewicz

(Wędrowiec), Wojciech Frykowski (Sprzedawca kiełbasek)

Film czarno-biały

Produkcja: Wojciech Frykowski dla Studia Małych Form Filmowych

Se-Ma-For w Łodzi, 1961

Długość filmu: $287 \mathrm{~m}$

Czas projekcji: 10 minut 15 sekund

Grand Prix na Międzynarodowym Festiwalu Filmów Krótkometrażowych w Tours, 1962; Dyplom Honorowy VIII Międzynarodowego Festiwalu Filmów Krótkometrażowych w Oberhausen, 1963

\section{Podziękowania}

Osobiste podziękowania za pomoc okazana autorowi podczas pracy nad niniejszym artykułem zechca przyjąć następujące osoby: Andrzej Kostenko, Krzysztof Kozłowski, Mieczysław Kuźmicki, Katarzyna Mąka-Malatyńska, Marcin Malatyński, Andrzej Szpulak, Andrzej Idon Wojciechowski, Jerzy Wójcik i Adam Wyżyński. 